\title{
Diet, feeding behavior, and surface morphology of the multi-armed Antarctic sea star Labidiaster annulatus (Echinodermata: Asteroidea)
}

\author{
John H. Dearborn, Kelly C. Edwards, David B. Fratt* \\ Department of Zoology, University of Maine, Orono, Maine 04469, USA
}

\begin{abstract}
Labidiaster annulatus is a large, multi-armed sea star common in moderate depths along the Antarctic Peninsula and off the islands of the Scotia Arc. Analyses by frequency of occurrence and several volumetric methods of stomach contents from 194 individuals from South Georgia, the South Sandwich Islands, and the Antarctic Peninsula show L. annulatus is an active and opportunistic predator and scavenger on prey from at least 10 phyla. Most common prey are euphausiids and amphipods which are caught initially by large, crossed, toothed pedicellariae arranged in wreaths on annuli along the arms and subsequently retained and passed to the oral surface and along the ambulacral groove to the mouth by the action of flexible arms and tube feet. L. annulatus obtains food, including activelyswimming crustaceans and small fish, directly from the water column, and to a lesser degree from within and on the substrate. Patterns of surface ciliation suggest that no methods of feeding involving cilia are utilized. Differences in the size and function of crossed pedicellariae, sources and types of prey and methods of prey capture now suggest that $L$. annulatus is not an ecological equivalent of Pycnopodia helianthoides from western North America.
\end{abstract}

\section{INTRODUCTION}

Reviews on aspects of the feeding biology of asteroids (Sloan 1980, Jangoux 1982, Menge 1982), on perception of food by echinoderms (Sloan \& Campbell 1982), on various other topics on echinoderm nutrition (Jangoux \& Lawrence 1982), and extensive summaries on Antarctic benthos (Dell 1972, White 1984, Picken 1985, Dayton 1990) confirm that our knowledge of the diets and feeding biology of asteroids is based largely on studies in temperate zones. There are few investigations of even the most common of the more than 240 species of asteroids which occur south of $35^{\circ} \mathrm{S}$ latitude. With the exception of the ecological studies on benthos at McMurdo Sound (Dayton 1972, Dayton et al. 1974), Adelie Land and other coastal sites (Arnaud 1964, $1970,1974)$, and the Ross Sea and Antarctic Peninsula (Pearse 1965, 1969, Dearborn 1977) few data are available on the foods and feeding habits of asteroids on the

- Present address: Alliance Technologies Corporation, Boott Mills South, Foot of John Street, Lowell, Massachusetts 01852, USA.
Antarctic Shelf. The trophic dynamics of asteroids is of interest because this group forms such an important component of the motile benthic biomass in high southern latitudes.

The multi-armed genus Labidiaster, within the asteriid subfamily Labidiasterinae, has 2 species. Labidiaster radiosus Lütken, 1871 is known from both coasts of southern South America and the Falkland Plateau and occurs as far north as the Brazilian Basin (Carrera-Rodriguez \& Tommasi 1977). Labidiaster annulatus Sladen, 1889, the more southern form, is known from the Balleny Islands (but not the Ross Sea), the Kerguelen Islands, Heard Island, Peter I Island, numerous sites around the Scotia Arc, and south along the Antarctic Peninsula to at least Marguerite Bay on the west coast of the Antarctic Peninsula (Bernasconi 1956, 1964, 1970, Clark 1962, Fell \& Dorsey 1969, McKnight 1976). The bathymetric range is from the intertidal (Bernasconi 1970) to $554 \mathrm{~m}$ (Fell \& Dawsey 1969, Bernasconi 1970, McKnight 1976, present study) but most occurrences are at 30 to $400 \mathrm{~m}$.

Labidiaster annulatus reaches very large size [R (centre of disc to tip of longest arm) $=$ at least $370 \mathrm{~mm}]$ and the number of arms may exceed 50 , more than for 
any other known asteroid (Fisher 1940, J. H. Dearborn pers. obs.). Within its range the species can be locally abundant, occurs on a wide variety of substrates, and has a catholic diet with crustaceans predominating. It is one of the few sea stars able to capture live prey from the water column (Dearborn 1977, Dearborn et al. 1978, 1982).

Little is known about the biology of Labidiaster annulatus. Fisher (1940) commented on morphology and recorded stomach contents of 3 specimens. Dearborn (1977) reported on an analysis of the stomach contents of 37 specimens collected near Anvers Island on the west side of the Antarctic Peninsula and presented bottom photographs which indicated extreme flexibility of the arms. These accounts do not provide detailed information on diet and feeding.

In this study we report on the stomach contents of Labidiaster annulatus from South Georgia, the South Sandwich Islands, and along the west side of the Antarctic Peninsula, describe and discuss feeding methods, and describe surface morphology at the gross and scanning electron microscope (SEM) levels, particularly in relation to feeding procedures.

\section{MATERIALS AND METHODS}

Sample collections. We collected 194 specimens of Labidiaster annulatus by trawl at 21 stations between 1975 and 1982 (Table 1). We obtained samples in 1975 from the ARA 'Islas Orcadas' off South Georgia and the South Sandwich Islands (DeWitt 1976, DeWitt et al. 1976, Dearborn et al. 1978), and in 1981 and 1982 from the RV 'Hero' along the Antarctic Peninsula (Dearborn et al. 1983, 1984). Trawl hauls of short duration minimized contamination and regurgitation during capture, but the possibility of the latter could not be excluded completely. We sorted and isolated individuals and for each one measured $R$ and $r$ (center of disc to disc margin) to the nearest $1 \mathrm{~mm}$, and recorded the total number of arms. We collected stomach contents by cutting open and laying back the aboral surface of the disc and carefully removing any ingested material in the lumen of the gut. Stomach contents were preserved in $70 \%$ ethanol.

Bottom photography. We obtained sea floor photographs with a Benthos, Inc. (North Falmouth, MA 02556, USA) Model 371 underwater camera and model 381 utility flash. The camera, flash, and an underwater compass with current vane were attached to a metal frame. A weight suspended 1.5 to $2.6 \mathrm{~m}$ below the frame triggered a Model 394 bottom contact switch (Dearborn et al. 1983) each time the weight hit the bottom. Direction of bottom current was determined by orientation of the compass vane.
Analyses of stomach contents. We examined stomach contents with a Wild M5 dissecting microscope and identified individual items to the lowest taxon possible.

We estimated the diet of Labidiaster annulatus by 2 methods. One was frequency of occurrence of food items. All specimens were analyzed in this way. The other was a points method which gave an estimate of the volumetric contributions of individual food items. Only specimens from the RV 'Hero' collections in 1981 and 1982 were analyzed in this manner. Presence or absence of food was noted to determine the number of specimens feeding. Frequency of occurrence of individual food items was then expressed as a percentage of feeding individuals. The points method of analysis was modified from Brun (1972) and Fratt \& Dearborn (1984). In this method points are assigned to the fullness condition of a particular food item. Our points scale ranged from 0 (empty) and 1 (trace) to 16 (maximum fullness) with intermediate states indicated by 2 , 4,8 , and 12. After determining an overall fullness score, we allocated points to each food type. These were later summed, then divided by the combined points assigned to all food items to compute the relative volume represented by each food item within the guts of members of all or particular populations (i.e. all individuals from a particular station or from multiple stations at a given locality).

Trace amounts of a single item within an otherwise empty gut could result in anomalously high point values assigned to that food item. For example, if a gut was empty apart from a trace of sediment the initial stomach fullness would be counted as 1 and the corresponding points given to the item sediment would be 16 (it being the only item in the gut). Likewise, a gut maximally filled with sediment would be given a fuliness value of 16, and sediment would be assigned a total of 16 points (again being the only item in the gut). This results in a trace of sediment and a gut full of sediment being assigned the same number of points. To minimize this bias toward trace amounts we adopted a modified fullness relative volume (FRV) method (Dearborn et al. 1986, Ferrari \& Dearborn 1989). In this system the points assigned to each food item within the gut are multiplied by the fullness index before being summed. In the above case this results in the trace gut being assigned 16 points for sediment $(1 \times 16)$, and the full gut being assigned 256 points for sediment $(16 \times 16)$, thus more closely reflecting the true volume relationship. This fullness modification of the points method results in little change in the proportions of those food items that have substantial representation in the gut, but is important for food items that occur as traces and thus tend to be overrepresented in the final volume analyses. These 3 types of data are all presented in the tables herein so that 
Table 1. Station data for collections of Labidiaster annulatus

\begin{tabular}{|c|c|c|c|c|c|c|c|c|}
\hline Cruise & $\begin{array}{l}\text { Stn } \\
\text { no. }\end{array}$ & $\begin{array}{l}\text { Total no of } \\
\text { specimens } \\
\text { collected }\end{array}$ & $\begin{array}{l}\text { Total no of } \\
\text { specimens con- } \\
\text { taining food }\end{array}$ & Date & $\begin{array}{c}\text { Start } \\
\text { position }\end{array}$ & $\begin{array}{c}\text { Stop } \\
\text { position }\end{array}$ & Location & $\begin{array}{l}\text { Depth } \\
\text { (m) }\end{array}$ \\
\hline IS0575 & 10 & 10 & 0 & 12 May 1975 & $\begin{array}{l}53^{\circ} 47.8^{\prime} \mathrm{S} \\
37^{\circ} 26.7^{\prime} \mathrm{W}\end{array}$ & - & $\begin{array}{l}\text { South } \\
\text { Georgia }\end{array}$ & $165-234$ \\
\hline IS0575 & 21 & 1 & 0 & 16 May 1975 & $\begin{array}{l}53^{\circ} 57.5^{\prime} \mathrm{S} \\
37^{\circ} 20.7^{\prime} \mathrm{W}\end{array}$ & - & $\begin{array}{l}\text { South } \\
\text { Georgia }\end{array}$ & $27-40$ \\
\hline IS0575 & 26 & 1 & 0 & 17 May 1975 & $\begin{array}{l}53^{\circ} 43.1^{\prime} \mathrm{S} \\
36^{\circ} 49.3^{\prime} \mathrm{W}\end{array}$ & - & $\begin{array}{l}\text { South } \\
\text { Georgia }\end{array}$ & $183-192$ \\
\hline IS0575 & 36 & 4 & 2 & 22 May 1975 & $\begin{array}{l}56^{\circ} 59.9^{\prime} \mathrm{S} \\
26^{\circ} 43.7^{\prime} \mathrm{W}\end{array}$ & - & $\begin{array}{l}\text { South } \\
\text { Sandwich Is. }\end{array}$ & $146-527$ \\
\hline IS 0575 & 53 & 1 & 0 & 26 May 1975 & $\begin{array}{l}57^{\circ} 41.4^{\prime} \mathrm{S} \\
26^{\circ} 22.3^{\prime} \mathrm{W}\end{array}$ & - & $\begin{array}{l}\text { South } \\
\text { Sandwich Is. }\end{array}$ & $355-468$ \\
\hline IS0575 & 61 & 45 & 33 & 30 May 1975 & $\begin{array}{l}56^{\circ} 42.3^{\prime} \mathrm{S} \\
27^{\circ} 00.4^{\prime} \mathrm{W}\end{array}$ & - & $\begin{array}{l}\text { South } \\
\text { Sandwich Is. }\end{array}$ & $93-121$ \\
\hline IS0575 & 67 & 3 & 1 & 31 May 1975 & $\begin{array}{l}56^{\circ} 44.6^{\prime} \mathrm{S} \\
27^{\circ} 02.7^{\prime} \mathrm{W}\end{array}$ & - & $\begin{array}{l}\text { South } \\
\text { Sandwich Is. }\end{array}$ & $137-155$ \\
\hline IS0575 & 76 & 9 & 4 & 3 Jun 1975 & $\begin{array}{l}56^{\circ} 15.6^{\prime} \mathrm{S} \\
27^{\circ} 35.0^{\prime} \mathrm{W}\end{array}$ & - & $\begin{array}{l}\text { South } \\
\text { Sandwich Is. }\end{array}$ & $110-155$ \\
\hline IS0575 & 78 & 31 & 26 & 4 Jun 1975 & $\begin{array}{l}56^{\circ} 20.2^{\prime} \mathrm{S} \\
27^{\circ} 30.4^{\prime} \mathrm{W}\end{array}$ & - & $\begin{array}{l}\text { South } \\
\text { Sandwich Is. }\end{array}$ & $123-141$ \\
\hline IS0575 & 90 & 3 & 3 & 7 Jun 1975 & $\begin{array}{l}54^{\circ} 50.6^{\prime} \mathrm{S} \\
37^{\circ} 23.8^{\prime} \mathrm{W}\end{array}$ & - & $\begin{array}{l}\text { South } \\
\text { Georgia }\end{array}$ & $223-227$ \\
\hline IS0575 & 97 & 1 & 1 & 10 Jun 1975 & $\begin{array}{l}54^{\circ} 12.4^{\prime} \mathrm{S} \\
37^{\circ} 40.1^{\prime} \mathrm{W}\end{array}$ & - & $\begin{array}{l}\text { South } \\
\text { Georgia }\end{array}$ & $69-90$ \\
\hline IS0575 & 99 & 1 & 1 & 10 Jun 1975 & $\begin{array}{l}54^{\circ} 12.3^{\prime} \mathrm{S} \\
37^{\circ} 36.5^{\prime} \mathrm{W}\end{array}$ & - & $\begin{array}{l}\text { South } \\
\text { Georgia }\end{array}$ & $79-90$ \\
\hline IS0575 & 101 & 2 & 2 & 10 Jun 1975 & $\begin{array}{l}54^{\circ} 14.1^{\prime} \mathrm{S} \\
37^{\circ} 54.2^{\prime} \mathrm{W}\end{array}$ & - & $\begin{array}{l}\text { Suuth } \\
\text { Georgia }\end{array}$ & $165-183$ \\
\hline HE81-2 & 18 & 19 & 18 & 23 Feb 1981 & $\begin{array}{l}64^{\circ} 47^{\prime} 28^{\prime \prime} \mathrm{S} \\
64^{\circ} 07^{\prime} 24^{\prime \prime} \mathrm{W}\end{array}$ & - & $\begin{array}{l}\text { Western } \\
\text { Peninsula }\end{array}$ & $68-85$ \\
\hline HE81-2 & 19 & 31 & 23 & 23 Feb 1981 & $\begin{array}{l}64^{\circ} 47^{\prime} 16^{\prime \prime} \mathrm{S} \\
64^{\circ} 06^{\prime} 30^{\prime \prime} \mathrm{W}\end{array}$ & - & $\begin{array}{l}\text { Western } \\
\text { Peninsula }\end{array}$ & $100-110$ \\
\hline HE82-4 & 14 & 6 & 1 & $19 \operatorname{Mar} 1982$ & $\begin{array}{l}64^{\circ} 48.6^{\prime} \mathrm{S} \\
64^{\circ} 04.0^{\prime} \mathrm{W}\end{array}$ & $\begin{array}{l}64^{\circ} 48.2^{\prime} \mathrm{S} \\
64^{\circ} 04.0^{\prime} \mathrm{W}\end{array}$ & $\begin{array}{l}\text { Western } \\
\text { Peninsula }\end{array}$ & $70-150$ \\
\hline $\mathrm{HE} 82-4$ & 18 & 1 & 0 & 22 Mar 1982 & $\begin{array}{l}64^{\circ} 18.5^{\prime} \mathrm{S} \\
62^{\circ} 58.6^{\prime} \mathrm{W}\end{array}$ & $\begin{array}{l}64^{\circ} 19.0^{\prime} \mathrm{S} \\
62^{\circ} 58.0^{\prime} \mathrm{W}\end{array}$ & $\begin{array}{l}\text { Western } \\
\text { Peninsula }\end{array}$ & $85-130$ \\
\hline HE82-4 & 20 & 1 & 0 & $22 \operatorname{Mar} 1982$ & $\begin{array}{l}64^{\circ} 18.2^{\prime} \mathrm{S} \\
62^{\circ} 58.1^{\prime} \mathrm{W}\end{array}$ & $\begin{array}{l}64^{\circ} 18.4^{\prime} \mathrm{S} \\
62^{\circ} 58.0^{\prime} \mathrm{W}\end{array}$ & $\begin{array}{l}\text { Western } \\
\text { Peninsula }\end{array}$ & $155-185$ \\
\hline HE82-4 & 21 & 6 & 1 & 23 Mar 1982 & $\begin{array}{l}64^{\circ} 21.4^{\prime} \mathrm{S} \\
61^{\circ} 28.2^{\prime} \mathrm{W}\end{array}$ & $\begin{array}{l}64^{\circ} 21.7^{\prime} \mathrm{S} \\
61^{\circ} 29.8^{\prime} \mathrm{W}\end{array}$ & $\begin{array}{l}\text { Western } \\
\text { Peninsula }\end{array}$ & $110-155$ \\
\hline $\mathrm{HE} 82-4$ & 22 & 6 & 5 & 23 Mar 1982 & $\begin{array}{l}64^{\circ} 22.3^{\prime} \mathrm{S} \\
61^{\circ} 28.3^{\prime} \mathrm{W}\end{array}$ & $\begin{array}{l}64^{\circ} 22.1^{\prime} \mathrm{S} \\
61^{\circ} 29.3^{\prime} \mathrm{W}\end{array}$ & $\begin{array}{l}\text { Western } \\
\text { Peninsula }\end{array}$ & $60-152$ \\
\hline HE $82-4$ & 41 & 12 & 7 & 29 Mar 1982 & $\begin{array}{l}64^{\circ} 48.4^{\prime} \mathrm{S} \\
64^{\circ} 07.0^{\prime} \mathrm{W}\end{array}$ & - & $\begin{array}{l}\text { Western } \\
\text { Peninsula }\end{array}$ & $88-112$ \\
\hline
\end{tabular}

direct comparisons can be made with information on food habits from other studies.

Laboratory observations. One of us (D.B.F.) used a flow-through aquarium (Fratt \& Dearborn 1984) at the Palmer Station Laboratory during the austral summer of 1982 to make observations and obtain photographs of the feeding strategies of living Labidiaster annulatus.

Microscopy. We took all tissue samples for SEM from a single, average-sized ( $\mathrm{R}=245 \mathrm{~mm}, \mathrm{r}=38 \mathrm{~mm})$ individual obtained at Stn 18 during Cruise HE81-2 (Table 1) and maintained in a circulating seawater tank at Palmer Station for several weeks prior to use Excised tissue samples were fixed and stored in phosphate-buffered $1 \%$ glutaraldehyde $4 \%$ formalin (McDowell 1978). We prepared samples for viewing by dehydrating in a graded ethanol series, critical-point drying from liquid carbon dioxide, and sputter-coating with from 20 to $40 \mathrm{~nm}$ of gold/palladium. Observations were carried out using an AMR-1000A scanning electron microscope. Sections of material for light microscopy were prepared with the same fixative, embedded in paraffin, sectioned at 4 to $6 \mu \mathrm{m}$ and stained with Masson's Trichrome. 


\section{RESULTS}

\section{General ecology}

The 194 specimens of Labidiaster annulatus examined in this study ranged in size from large $(\mathrm{R}=$ $338 \mathrm{~mm}, \mathrm{r}=43 \mathrm{~mm})$ to small $(\mathrm{R}=21 \mathrm{~mm}, \mathrm{r}=4 \mathrm{~mm})$ with a mean $R$ value of $219 \mathrm{~mm}$. They occurred on a variety of bottom types including mud and sand, mud and small stones, and gravel and rocks (Fig. 1) and often were associated with large hexactinellid sponges (Fig. 1e to f) or 'forests' of sponges, colonial cnidarians and bryozoans. Depths of capture ranged from 27 to $527 \mathrm{~m}$ (Table 1). Numbers of specimens taken at individual stations ranged from 1 to 4.5 (mean $=9.2$ ). Mean numbers per station for different geographic regions were, respectively, South Georgia, 2.7; South Sandwich Islands, 15.5; and the western coast of the Antarctic Peninsula, 10.3. Largest numbers of $L$. annulatus occurred at stations which had mixed substrates of mud, gravel, and small rocks and a diverse and dense assemblage of both sessile and motile benthos. Common faunal elements at these stations were small to medium encrusting and free-standing sponges, cnidarians (especially gorgonians), polychaetes, bryozoans, amphipods, isopods, and other echinoderms.

The posture of Labidiaster annulatus varies greatly depending on activity (Fig. 1; Dearborn 1977. Fig. 1). The body may be held flat against the substrate with the arms more or less equally spaced (Fig. 1a to c) or the individual may be on sponges, rocks or other objects and hold on with a few arms with others extended for feeding (Fig. 1e to f). The arms are extremely long and flexible and may be curved or coiled individually or in groups during locomotion or feeding (Figs. 1d, f \& 2).

Examination of bottom photographs in which both the current vane and Labidiaster annulatus were present showed no clear relationship between direction of bottom current and sea star posture.

\section{Diet}

Of the 194 individuals collected, 128 (65.9\%) contained food (Tables $2 \& 3$ ). The percentage of individuals feeding at different stations ranged from 0 to 100 The majority of individuals containing food had fed on only 1 or 2 food types although in a few instances as many as 6 types were present in a gut at the same time. Often a single food dominated at a particular station. e.g. amphipods at Stn 61 (Cruise IS0575) off Visokoi Island and krill at Stns 18 and 19 (Cruise HE81-2) off Janus Island near Arthur Harbor (Table 3). Mean stomach fullness also varied widely but exceeded one half of the maximum observed value at only that one pair of Janus Island stations.

Stomach contents of Labidiaster annulatus included members of at least 10 phyla (Table 4). Components were separated into 23 (Table 2) or 22 (Table 3) categories. Because of the relatively small sample sizes obtained at all sites no statistical comparisons between stations were made.

Euphausiids (krill), amphipods, and sediment were the 3 most important stomach contents by all 3 methods of analysis. Krill occurred in $62.5 \%$ of the individuals containing food and were by far the dominant prey in both volume analyses (Table 2). They were often intact and fresh within sea star stomachs, suggesting live capture. Much krill material from stomachs was not intact, however, and may have been moribund near the bottom, or dead at the time of capture

The percent frequency of amphipods, the second most important diet item, was 38.2 but their smaller sizes relative to krill resulted in percent relative volume (RV) and fullness relative volume (FRV) values of only 7.1 and 5.8, respectively (Table 2).

Sediment was considered a regular (food) category in our analyses but we did not determine the specific microflora and fauna on the surface of sediment particles to estimate the contributions these organisms may have made to the nutrition of this sea star. Sediment ranked third by percent frequency of occurrence (26.5) but second in both volume percentages, 16.4 and 12.8 , respectively (Table 2). Sediment was found in $65.8 \%$ of the individuals taken near Janus Island, together with a relatively high percentage of foraminiferans (12.1) and dominant krill (90.2\%) (Table 3). Patches of mud and sand occur at that location. Sediment was not present, however, in any stomachs of individuals from Visokoi and Zavodovski Islands. In these locations the sediment is largely coarse basaltic gravel with a poorly established sessile epifauna where we sampled and Labidiaster annulatus there fed almost entirely on amphipods and krill (Table 3 ).

All remaining food items ranked 7.0 or less in percent frequency of occurrence and 2.4 or less in percent FRV. By the first measure asteroids and foraminiferans were next in importance. By FRV fish and gastropods were next, followed by asteroids, unidentified crustacean remains, and mysids. In all cases, digestion of fish had proceeded so far that specific identifications were not possible. The largest piece of fish found in a stomach was $62 \mathrm{~mm}$ in length.

Labidiaster annulatus feeds on smaller individuals of its own species and several types of ophiuroids, including large species with disc diameters to at least $36 \mathrm{~mm}$. Off South Georgia Ophionotus hexactis was occasionally taken as prey and farther south at the South Sandwich Islands and along the Antarctic Peninsula 

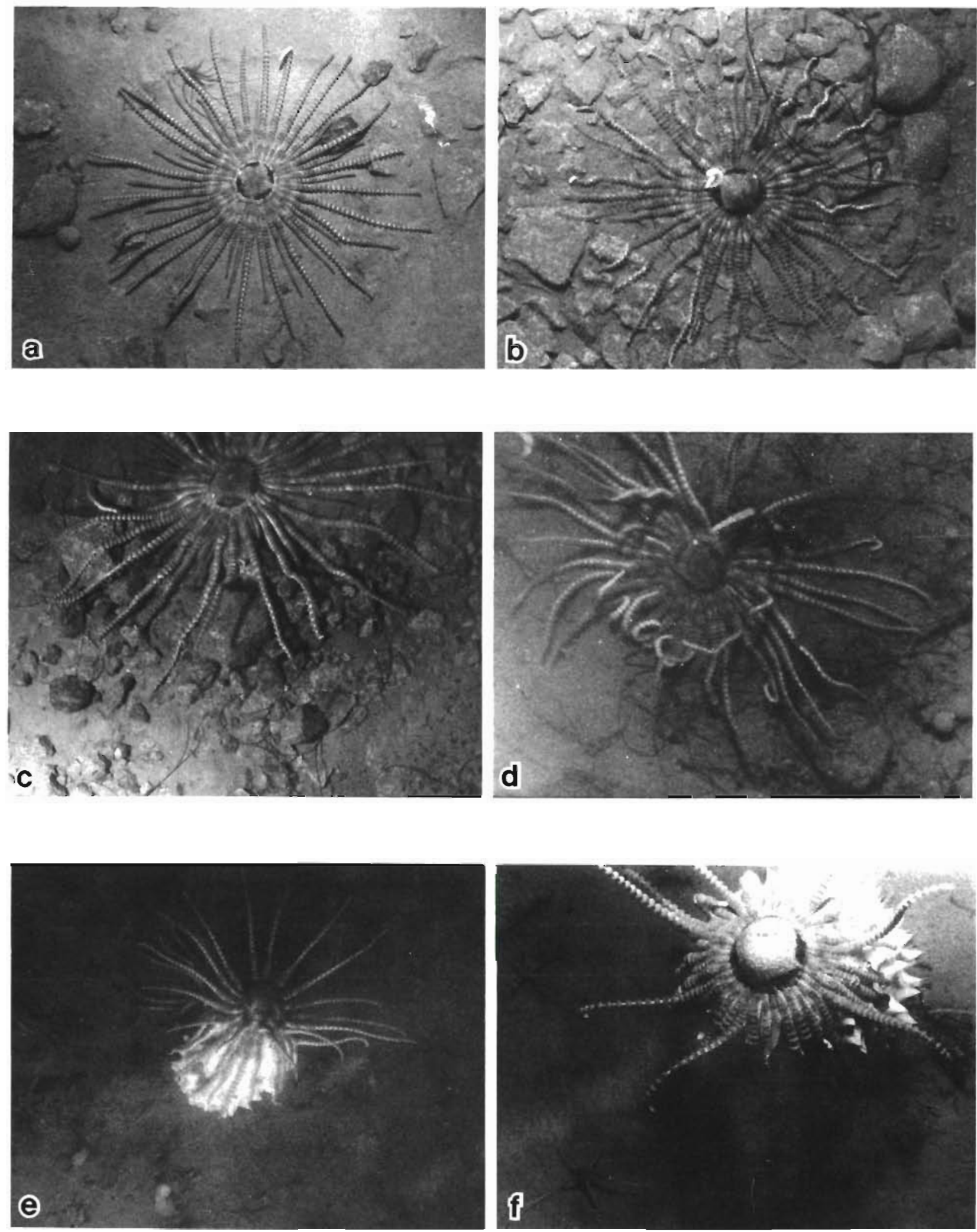

Fig. 1. Labidiaster annulatus on the sea floor. Annuli bearing pedicellariae are visible on the arms. (a to d) Specimens on mixed substrates off Hermit Island near Arthur Harbor, Antarctic Peninsula, 98 to $104 \mathrm{~m}, 20$ Mar 1982. (e, f) Specimens on hexactinellid sponges west of Valdivia Point, northeastern Gerlache Strait, 117 to $149 \mathrm{~m}, 23$ Mar 1982. Note inflated disc of the individual in (f) and the brittle star (probably Ophionotus victoriae) at lower left 
Table 2. Labidiaster annulatus. Summary of stomach contents, all stations combined. N: number of occurrences; \%: percent frequency of occurrence; RV: percent composition by relative volume; FRV percent composition by fullness relative volume. Total $\mathrm{N}=194, \mathrm{~N}$ (feeding) $=128(65.9 \%) ; \mathrm{N}$ for volume determinations $=82, \mathrm{~N}$ (feeding, volume determinations) $=55(67.0 \%)$

\begin{tabular}{|c|c|c|c|c|c|c|c|}
\hline Item & $N$ & $\%$ & Rank & RV & Rank & FRV & Rank \\
\hline Foraminifera & 7 & 5.46 & 5 & 1.48 & 7 & 1.15 & 10 \\
\hline Sponge fragments & 5 & 3.90 & 6 & 0.53 & 12 & 0.66 & 13 \\
\hline Hydroid fragments & 1 & 0.78 & 20 & 0.10 & 19 & 0.06 & 21 \\
\hline Nematoda & 1 & 0.78 & 20 & 0.10 & 19 & 0.12 & 20 \\
\hline Gastropoda & 2 & 1.56 & 17 & 1.06 & 11 & 2.43 & 4 \\
\hline Bivalvia & 3 & 2.34 & 13 & 0.31 & 16 & 0.48 & 14 \\
\hline Polychaeta & 4 & 3.12 & 9 & 0.42 & 13 & 0.36 & 18 \\
\hline Ostracoda & 2 & 1.56 & 17 & 0.21 & 18 & 0.24 & 19 \\
\hline Copepoda & 3 & 2.34 & 13 & 0.31 & 16 & 0.48 & 14 \\
\hline Mysidacea & 4 & 3.12 & 9 & 2.12 & 5 & 1.45 & 8 \\
\hline Isopoda & 4 & 3.12 & 9 & 1.48 & 7 & 1.21 & 9 \\
\hline Amphipoda & 49 & 38.28 & 2 & 7.10 & 3 & 5.83 & 3 \\
\hline Euphausiacea & 80 & 62.50 & 1 & 59.38 & 1 & 62.77 & 1 \\
\hline Unidentified crustaceans & 3 & 2.34 & 13 & 2.75 & 4 & 1.70 & 7 \\
\hline Ectoprocta & 2 & 1.56 & 17 & 1.48 & 7 & 0.97 & 11 \\
\hline Crinoidea & 3 & 2.34 & 13 & 0.42 & 13 & 0.42 & 17 \\
\hline Asteroidea & 9 & 7.03 & 4 & 1.69 & 6 & 2.37 & 6 \\
\hline Ophiuroidea & 5 & 3.90 & 6 & 0.21 & 18 & 0.48 & 14 \\
\hline Echinoidea & 1 & 0.78 & 20 & 0.10 & 19 & 0.06 & 21 \\
\hline Unidentified fish & 5 & 3.90 & 6 & 1.16 & 10 & 2.43 & 4 \\
\hline Unidentified fecal pellets & 4 & 3.12 & 9 & 0.42 & 13 & 0.72 & 12 \\
\hline Unidentified organic material & 1 & 0.78 & 20 & 0.10 & 19 & 0.06 & 21 \\
\hline Sediment & 34 & 26.56 & 3 & 16.43 & 2 & 12.83 & 2 \\
\hline
\end{tabular}

Ophionotus victoriae was taken. In one instance a large $L$ annulatus disgorged on deck 90 . victoriae with disc diameters 18 to $26 \mathrm{~mm}$. Some of the brittle stars were still alive and most had retained their arms. (Fig. $8 \mathrm{c}$ shows a tiny piece of an ossicle from an unidentified echinoderm prey stuck in the teeth of a crossed pedicellaria.)

\section{Feeding behavior}

Observations by two of us (D.B.F., K.C.E.) of live specimens held in aquaria at Palmer Station and of bottom photographs by all of us show that Labidiaster annulatus uses its flexible arms and large crossed pedicellariae to capture a variety of live prey and to scavenge organic debris.

On 20 and 23 February 1982, D.B.F. observed a juvenile $(\mathrm{R}=134 \mathrm{~mm}, \mathrm{r}=27 \mathrm{~mm})$ Labidiaster annulatus held at ambient temperature in an aquarium at Palmer Station. Two live adult Euphausia superba were introduced into the tank. Within 2 min one swimming krill had contacted the aboral arm surface of the sea star and was held fast at the antennae by pedicellariae. Within another minute the second euphausiid was captured by pedicellariae of another region of the aboral arm surface. After 10 min the first euphausid had escaped or been released following struggles involving rapid flips of the abdomen. During this period the 2 arms of the sea star adjacent to the arm holding the second krill bent upwards and toward the prey and at 15 min 3 to 11 arms were involved in entangling and passing the prey to the oral surface of the arms. Both pedicellariae and tube feet were involved in the process of holding and manipulating the krill but once firmly passed to the ambulacral surface the tube feet were used to pass the krill down the arm toward the mouth. During this process most arms continued to hold the sea star against the glass side of the aquarium. As the krill was brought close to the arm base, the disc was raised off the glass 3 to $4 \mathrm{~cm}$, and 7 or 8 adjacent arms bent under themselves to form an encasement around the prey. At about 22 min the krill was passed into the mouth, uropods first. The cardiac stomach was not everted.

Observations on krill predation by this individual and others (Fig. 2) suggest the following points about Labidiaster annulatus-krill interactions. Actively swimming krill contact the surfaces of raised arms of $L$. annulatus. Very brief contacts may not elicit a sea star response, but more prolonged contact causes large crossed pedicellariae to open and grasp the prey, often 
Table 3. Labidiaster annulatus. Percent frequency of occurrence of stomach contents from all stations combined and selected individual sites, together with percent volumes of stomach contents from the Janus Island material (see text)

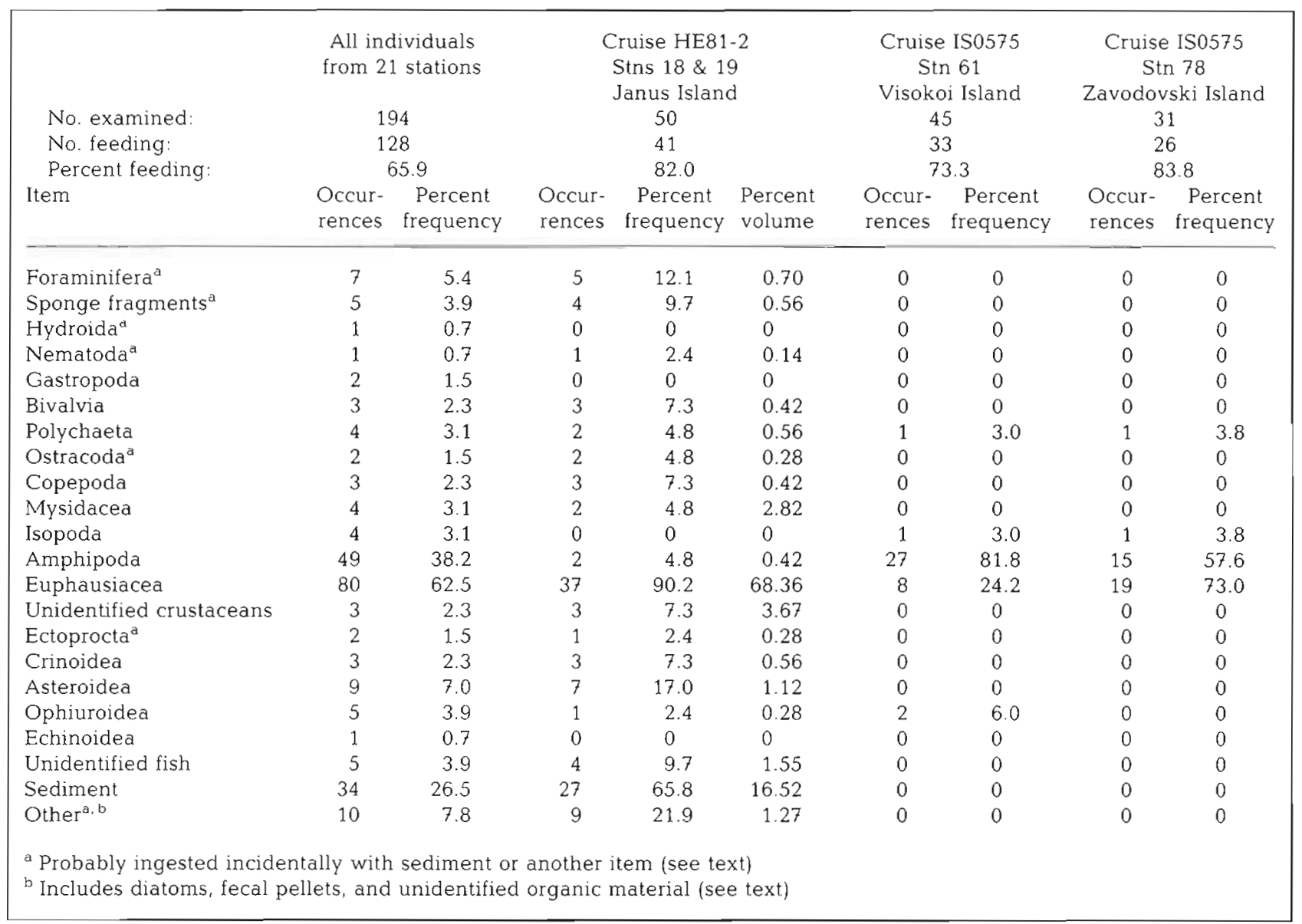

Table 4. Labidiaster annulatus. Stomach contents identified from sea stars collected at 21 stations in the Southern Ocean

\begin{tabular}{|lcc|}
\hline Sarcodina & Arthropoda & Echinodermata \\
Foraminifera & Ostracoda & Crinoidea \\
Porifera & Podocopida & Promachocrinus kerguelensis \\
Hexactinelida & Copepoda & Asteroidea \\
Unidentified sponge fragments & Calanoida & Labidiaster annulatus \\
Nematoda & Unidentified copepods & Ophionotus hexactis \\
Mollusca & Mysidacea & Ophionotus victoriae \\
Gastropoda & Antarctomysis maxima & Amphiuridae \\
Rissoa cf. sulcata & Unidentified mysids & Echinoidea \\
Rissoa cf. fuegoensis & Isopoda & Sterechinus neumayeri \\
Rissoa sp. & Amphipoda & Fish and fish scales \\
Cithna? & Gammaroidea & Fecal pellets (unidentified) \\
Bivalvia & Euphausiacea & Other \\
Genaxinus bongraini & Euphausia superba & Triangular and other diatoms \\
Unidentified shell fragments & Unidentified euphausiids & Unidentified microfragments \\
Annelida & Unidentified crustaceans & Unidentified organic material \\
Unidentified errant polychaetes & Ectoprocta (Bryozoa) & Sediment \\
Unidentified polychaetes & Emballotheca phylactelloides & \\
Polychaete tubes & Unidentified fragments & \\
\hline
\end{tabular}



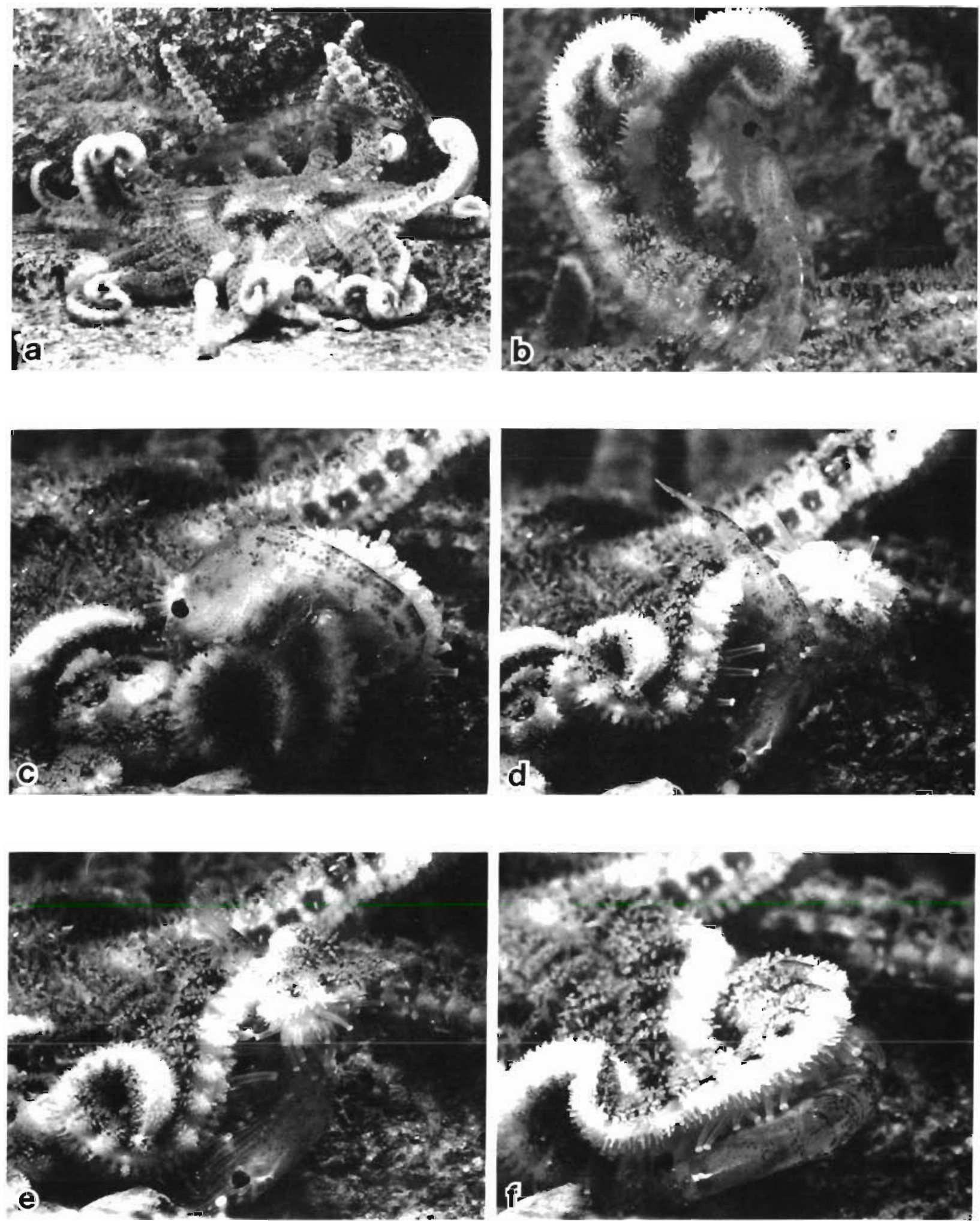

Fig. 2. Labidiaster annulatus feeding on Euphausia superba in the laboratory at Palmer Station. Photographs taken 3 Mar 1982 by D.B.F. Euphausiids in (a), (b), and the one in ( $\mathrm{c}$ to f) are not the same individual. (a) Individual krill swimming over sea star; note many arm tips are raised well off the bottom. (b) A krill specimen is held by its antennae and pleopods when it contacted pedicellariae on the sea star arm. (c to f) Subsequent manipulation of a euphausiid by pedicellariae and podia and transport down the arm toward the mouth. See text for details 
by antennae or appendages. Distal portions of adjacent arms then wrap around the prey which is transferred to the oral side of the arm. Tube feet then pass the struggling krill along the ambulacral groove toward the mouth. Ingestion of krill is frequently tail first, but may be anterior end first, or prey may be folded over and taken in sideways. The sea star mouth is capable of great expansion. Captured krill generally begin rapid abdominal flips as an escape response. Prey escape success depends on the number of holding pedicellariae involved and the quickness with which arms and tube feet are employed to further restrain the prey. These responses of the sea star are extremely variable. In one instance a euphausiid was held by pedicellariae on 2 adjacent arms for 7 min and yet escaped by abdominal flip. On other occasions krill were held for one to several hours and then escaped or were released. In one instance the active prey was within 1 to $2 \mathrm{~cm}$ of the mouth and escaped. Ingestion is much more certain with moribund krill without strong escape responses.

\section{Morphology}

The disc of Labidiaster annulatus is small in relation to the total diameter across the outstretched arms (Fig. 1). In life it is flexible and often expanded into a high dome depending on the amount of internal fluids present or the fullness of the gut (Fig. 1f). The most prominent feature of the aboral disc surface is the conspicuous madreporite (Figs. 1d \& 3a, d) situated near the disc edge. The madreporite is elevated above the general aboral surface. Its upper circumference is bordered by a ring of prominent spines (Fig. 3d). All surfaces of the madreporite are ciliated, especially those of the central radiating ridges. These ridges are least ciliated on their exposed upper surfaces and most ciliated on the deeper lateral surfaces which form the water channels.

Many large, prominent straight pedicellariae (Fig. 3e) occur on the aboral disc surface. Each has a short, fleshy pedestal connecting it to the general body surface and is capable of lateral movement. These pedicellariae are not elaborately toothed, unlike the prey-capturing pedicellariae of the arms. Straight pedicellariae keep the upper surfaces of the disc and arm bases free of debris and microorganisms. The epidermis of these pedicellariae is ciliated.

The arms of Labidiaster annulatus show distinct regional differences. Most apparent is the presence of numerous large, crossed pedicellariae organized into groups and carried on transverse integumentary welts or rings, termed annuli, largely on the outer two-thirds of the arms. The arm bases bear relatively few pedicel- lariae, generally the straight type, similar to those on the disc. Distinct annuli are not formed at the arm bases.

The arm skeleton is most developed proximally, with a well-established meshwork of lateral and aboral ossicles forming a relatively rigid structure (Fig. 3a, b). The aboral skeleton is gradually reduced further along the arm (Fig. 3c) and is very weak distally. The major structural support of the arm is provided by welldeveloped ambulacral ossicles. This structural organization permits the great flexibility of the arms, especially the distal one-third of each ray.

The annuli of the outer arms (Figs. 1f, 2b, 3c \& 4a) consist of large, fleshy rings, each of which bears a number of stalked, crossed pedicellariae. These crossed pedicellariae are generally not found in the spaces between annuli, although some individuals have a few small straight pedicellariae between annuli, especially toward the proximal end of the arm. In the living asteroid this organization creates a series of discrete rings of pedicellariae that become especially prominent when the stalked pedicellariae are erect (Figs. 1 \& 2). Annuli extend to the arm tip which is capped by a fleshy pad bearing a number of small, crossed pedicellariae (Fig. 4b).

The number of pedicellariae found on a single annulus varies with the position of the annulus along the arm and ranges from between 1 and 5 to 80 among adults (Table 5). The number of pedicellariae on individual arms of the same specimen varies considerably (Table 5). In general, the lowest numbers of pedicellariae per annulus are found toward the arm bases and higher numbers toward the arm tips (Tables 5 \& 6) except that the greatest numbers tend to occur about 5 to 8 annuli before the arm tip. Smaller specimens of Labidiaster annulatus demonstrate the same distribution of pedicellariae although the absolute numbers per annulus are lower (Table 6).

The pedicellariae of any given annulus tend to be closely packed (Fig. $4 \mathrm{a}, \mathrm{c}$ ). On most annuli regenerating pedicellariae and scars from missing pedicellariae are present. Fig. 4c illustrates both the stump of a removed pedicellaria and a very small regenerating one. Most of several hundred annuli show regenerating pedicellariae in various stages (Tables $5 \& 6$ ).

Arm surfaces are ciliated to varying degrees according to location. Interannular spaces have moderately dense ciliation (Fig. $4 \mathrm{~d}$ ) but the surfaces of annuli themselves are sparsely ciliated (Fig. 4e). Cilia at both locations increase in density toward the oral side of the arm. The annular surface immediately adjacent to pedicellariae and the stalks of pedicellariae themselves are generally not ciliated (Fig. 4f).

Each of the crossed, prey-capturing pedicellariae consists of 3 ossicles, 2 jaws and a basal element on 

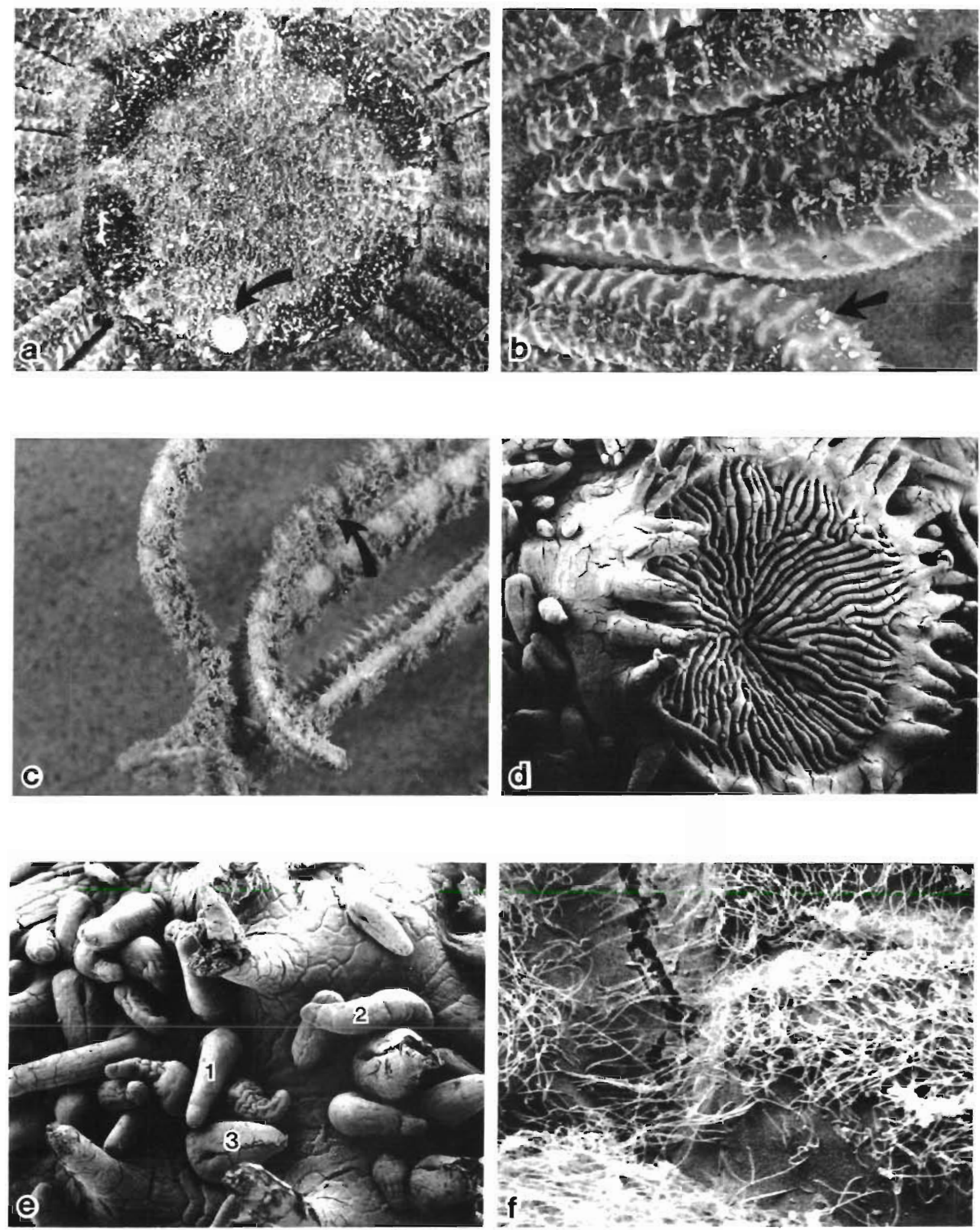

Fig. 3. Labidiaster annulatus. (a to $c$ ) Dried specimen ( $R=253 \mathrm{~mm}, \mathrm{r}=39 \mathrm{~mm}$ ). (a) Disc and madreporite (arrow). (b) Arm bases showing the widely-spaced aboral skeleton and large straight pedicellariae (arrow). (c) Distal portion of arms and arm tips with large crossed pedicellariae (arrow) on annuli. (d) Madreporite, $\times 14$. (e) Aboral surface near the madreporite; 1, spine; 2, papula; 3 , straight pedicellaria, $\times 22$. (f) Ciliation of the aboral surface, $\times 1200$ 

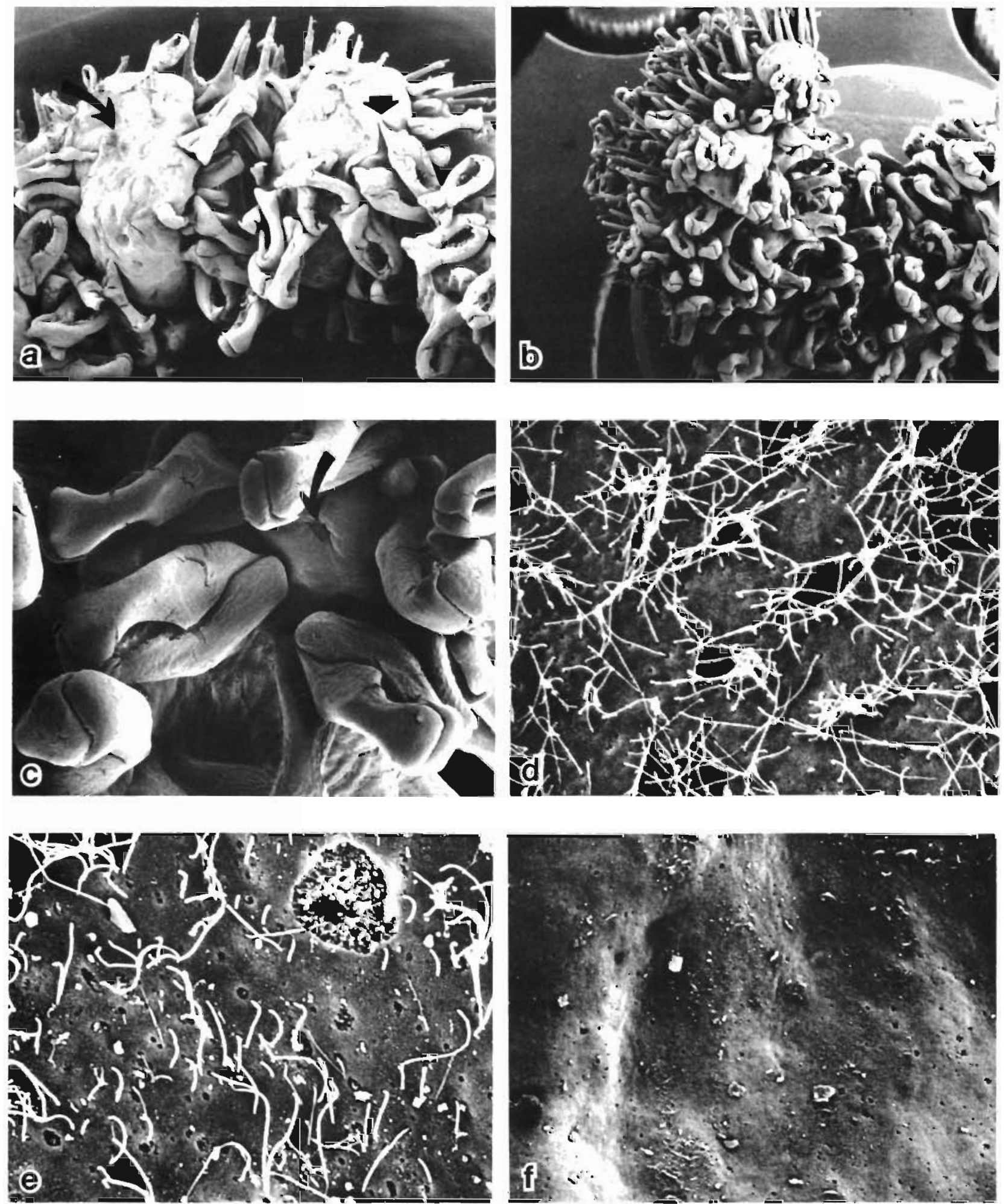

Fig. 4. Labidiaster annulatus. Crossed pedicellariae and surfaces of annuli (integumentary welts). (a) Crossed pedicellariae on 2 annuli of distal portion of the arm, $\times 13$. Curved (left) arrow indicates scar where a pedicellaria has been pulled free; right arrow indicates stalk of a crossed pedicellaria. (b) Arm tip showing high density of pedicellariae, $\times 13$. (c) Closeup of crossed pedicellariae on distal third of an arm, $\times 60$; note scar (arrow) where one pedicellaria has been pulled off. (d) Interannular ciliation, $\times 1100$. (e) Annular ciliation between stalks of pedicellariae, $\times 2000$. (f) Annulus surface at base of a pedicellaria stalk 
Table 5. Labidiaster annulatus. Variation in the mean number of crossed pedicellariae per annulus for 3 different regions of 5 adjacent arms of an adult $(\mathrm{R}=307 \mathrm{~mm}, \mathrm{r}=42 \mathrm{~mm})$. Five annuli were counted in each region. Pedicellariae from adult annuli are often missing or regenerating. Only complete and presumably functional pedicellariae were counted here

\begin{tabular}{|lrrrrrrr|}
\hline Portion of arm & Grand & \multicolumn{5}{c|}{ Arm number } \\
& mean & 1 & 2 & 3 & 4 & 5 \\
\hline Proximal & 8.0 & 3 & 9 & 7 & 11 & 10 \\
Middle & 39.0 & 26 & 26 & 50 & 54 & 39 \\
Distal, but not tip & 55.8 & 56 & 53 & 35 & 55 & 80 \\
& & & & & & &
\end{tabular}

Table 6. Labidiaster annulatus. Number of crossed pedicellariae per annulus for 5 juvenile specimens

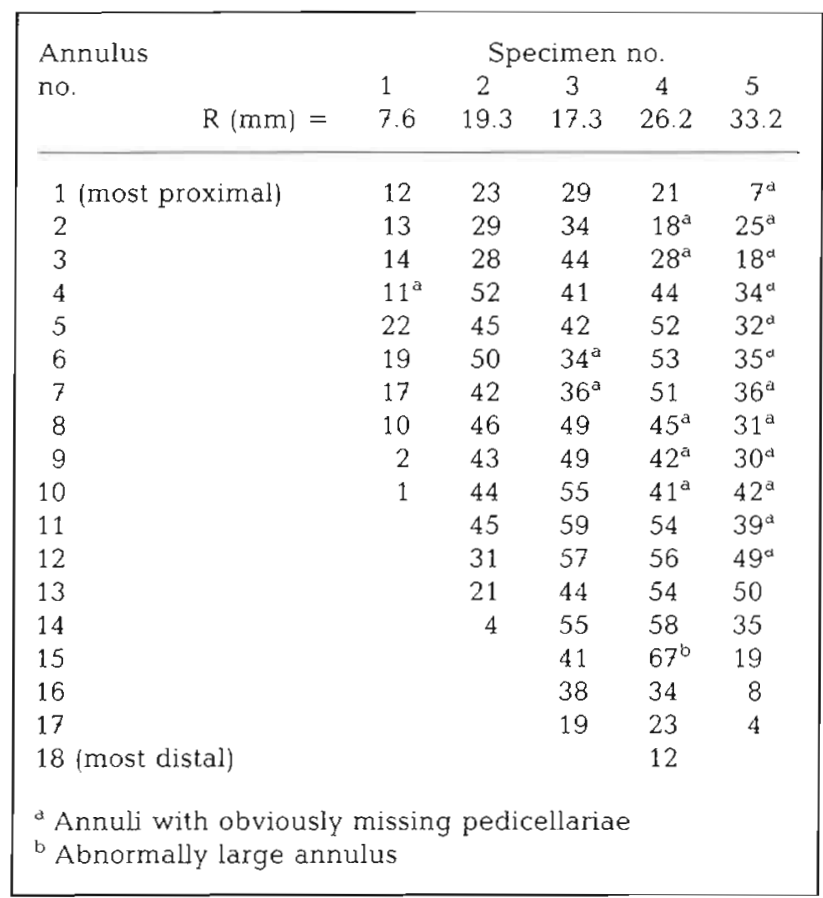

which the jaws pivot (Fig. 5b, c). Such pedicellariae of adults range to at least $1.3 \mathrm{~mm}$ in total length and individual jaws range up to $400 \mu \mathrm{m}$ across the toothed end. Each jaw bears an impressive armament of several different tooth sizes (Figs. 6 to 8 ). Most prominent are 2 large canine-like teeth often $200 \mu \mathrm{m}$ or more in length located at either corner of the distal end of the jaw.

Between the 'canines' is a double row of smaller teeth (Figs. 6, 7a \& 8). The inner row consists of generally 2 to 5 teeth each 50 to $75 \mu \mathrm{m}$ in length. Teeth of the outer row are more numerous but only about one half the length of the inner ones. Lateral to the 2 'canines' are several smaller teeth about equal in size to those of the outer row (Figs. $6 \& 8$ a). A prominent median row of teeth extends proximally down each jaw. These are often slightly recurved and at the proximal end of the row are doubled. Median tooth size decreases proximally.

The 'canines' and 2 distal rows of teeth interlock tightly when the jaws are closed. This is evident in both fresh and cleaned pedicellariae (Figs. 4c, 6a, b, c \& 8a). Pedicellariae occur in both right-handed and lefthanded configurations (compare Fig. 6a \& b) and both types can occur on any individual. Fig. 6d illustrates a pedicellaria opened to a moderate gape. The jaws, however, frequently are opened so far that they are nearly horizontal.

Teeth on pedicellariae of Labidiaster annulatus develop when the individual is quite small. An individual $(\mathrm{R}=7.6 \mathrm{~mm}, \mathrm{r}=1.6 \mathrm{~mm}$ ) had pedicellariae with incompletely formed jaws. The jaw was only about $125 \mu \mathrm{m}$, was spatulate and only slightly ribbed. The jaw of a larger specimen $(\mathrm{R}=17.3 \mathrm{~mm}, \mathrm{r}=3.7 \mathrm{~mm}$ ) was ca $175 \mu \mathrm{m}$ in length. These crossed pedicellariae exhibited nearly all adult characteristics, different mainly in size but not the extent of jaw armament.

The basal ossicle (Fig. 7b) is roughly S-shaped, with each curve forming an articulating surface and cradle for one jaw ossicle. The articulating surface for the corresponding jaw lies to the upper right. It connects with a similar surface lying horizontally across the midline of the back of the jaw (Fig. 6c). The proximal end of the jaw (Fig. $7 \mathrm{a}$, left) is held in the cradle below the articulation in a ball and socket arrangement. The outer end of the cradle wraps partially around the jaw, firmly locating it on the basal ossicle.

The basal ossicles of the smallest juvenile, like the pedicellarial jaws, are poorly developed. The articulation with the jaw consists of little more than a series of calcitic points, and the cradle is poorly developed. A larger juvenile ( $R=19.3 \mathrm{~mm}, \mathrm{r}=4.3 \mathrm{~mm}$ ) shows welldeveloped basal ossicles with all the adult characteristics in miniature.

The pedicellariae of the arm annuli extend to the borders of the ambulacral groove (Fig. 9a). A general reduction in size occurs in pedicellariae lying closer to the ambulacrum compared to those located aborally.

The suckered podia are paired and extremely extensible (Figs. $2 \& 9$ b). The podia and floor of the ambulacrum are not ciliated.

The adambulacral ossicles each bear a pair of orallydirected spines each side of the ambulacrum. The base of the outermost spine has a fleshy pad bearing a large number of small crossed pedicellariae (Fig. 9d). Each of these small pedicellariae is identical in structure to the large crossed pedicellariae of the annuli. Spines near the arm tip often lack the pad of pedicellariae (Fig. 9a). The innermost of the paired ambulacral spines generally carries no pedicellarial armament although a small group of 2 or 3 small straight pedicellariae is generally 

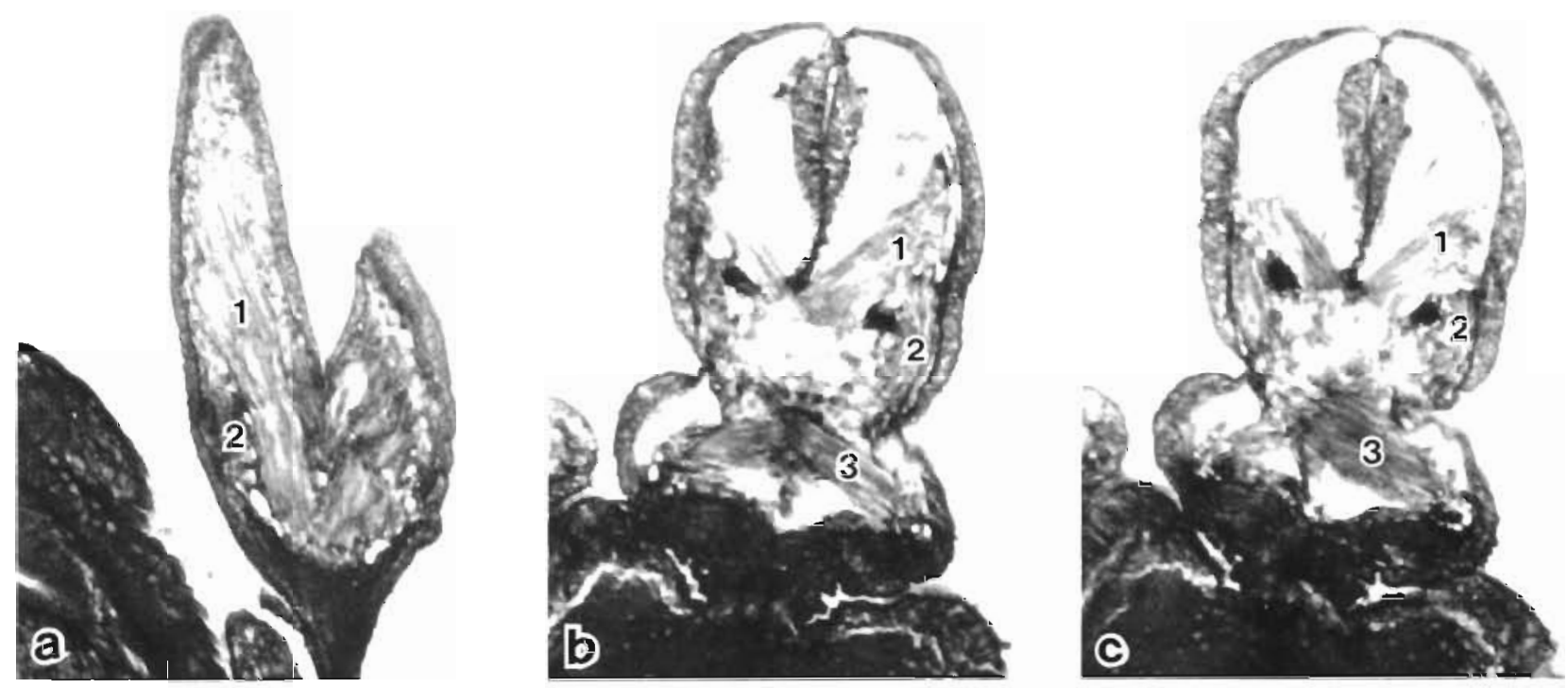

Fig. 5. Labidiaster annulatus. Light photomicrographs of sectioned pedicellariae. (a) Straight pedicellaria; 1 , adductor muscle; 2 , abductor muscle, $\times 100$. (b) Crossed pedicellaria; 1 , distal adductor muscle; 2 , abductor muscle; 3 , proximal adductor muscle. Dark spots near the center of the pedicellaria are connective tissue of the jaws and basal ossicle, $\times 100$. (c) Deeper section through the same pedicellaria as in (b). Numbered structures same as in (b). This section demonstrates that the proximal adductor originates on the basal ossicle and inserts on the proximal end of the jaw, $\times 100$

found within the ambulacrum just below the base of this spine (Fig. 9c). These pedicellariae are of similar construction to those found on the disc and arm bases and are attached to the surface of the adambulacral ossicles by a short stalk.

The ciliation of the aboral arm surfaces continues to the border of the ambulacrum where it gradually becomes reduced in density. None of the structures within the ambulacrum are ciliated. The adambulacral spines are moderately ciliated at their bases but unciliated at their tips (compare Fig. $9 e$ \& f).

The peristome is unciliated and extremely broad, covering the majority of the oral side of the disc. It is capable of great expansion and contraction, allowing the mouth to ingest extremely large prey items.

\section{DISCUSSION}

Labidiaster annulatus is a large, multi-armed, active and opportunistic asteroid predator and scavenger primarily found on the shelves of West Antarctica and the Scotia Arc. It is unusual in its numerous arms, large prey-capturing crossed pedicellariae, arrangement of spines and pedicellariae into wreaths on supporting transverse integumental annuli along the arms, extremely flexible distal arms, and ability to capture active crustaceans and fish from the water column (Dearborn 1977, this paper). This study shows that its diet is diverse (at least 10 phyla) and food may be obtained from within, on, or above the substrate. It eats live and moribund prey and consumes individual dead organisms and organic debris of various types. Its necrophagous habit is demonstrated by attraction to baited traps (Presler 1986, J. H. Dearborn pers obs.). In the absence of apparently preferred crustacean prey, availability of food is probably more important than type. L. annulatus frequently climbs on to structures or other organisms. This provides indirect evidence that it feeds heavily on active organisms obtained from the water column. The present study confirms Dearborn's (1977) observations that L. annulatus feeds primarily by holding its flexible arms up into the water column to capture active prey. However, the diversity of prey taken from on and in the substrate reported here, even though such dietary items generally occur at low frequencies of occurrence, suggests that $L$. annulatus has a broader spectrum of opportunistic feeding behaviors than previously recognized.

Labidiaster annulatus represents the extreme condition among multiarmed asteroids. Its morphology clearly reflects the adaptations of such sea stars suggested by Lawrence (1988) including increased ability to attach, increased flexibility of arms and numbers of tube feet for feeding and an increase in capacity for digestion.

Labidiaster annulatus consumes at least 36 distinct prey species or types (Table 3), yet only 3 of these, Euphausiacea, Amphipoda, and sediment, account for more than $10 \%$ frequency of occurrence. This ten- 

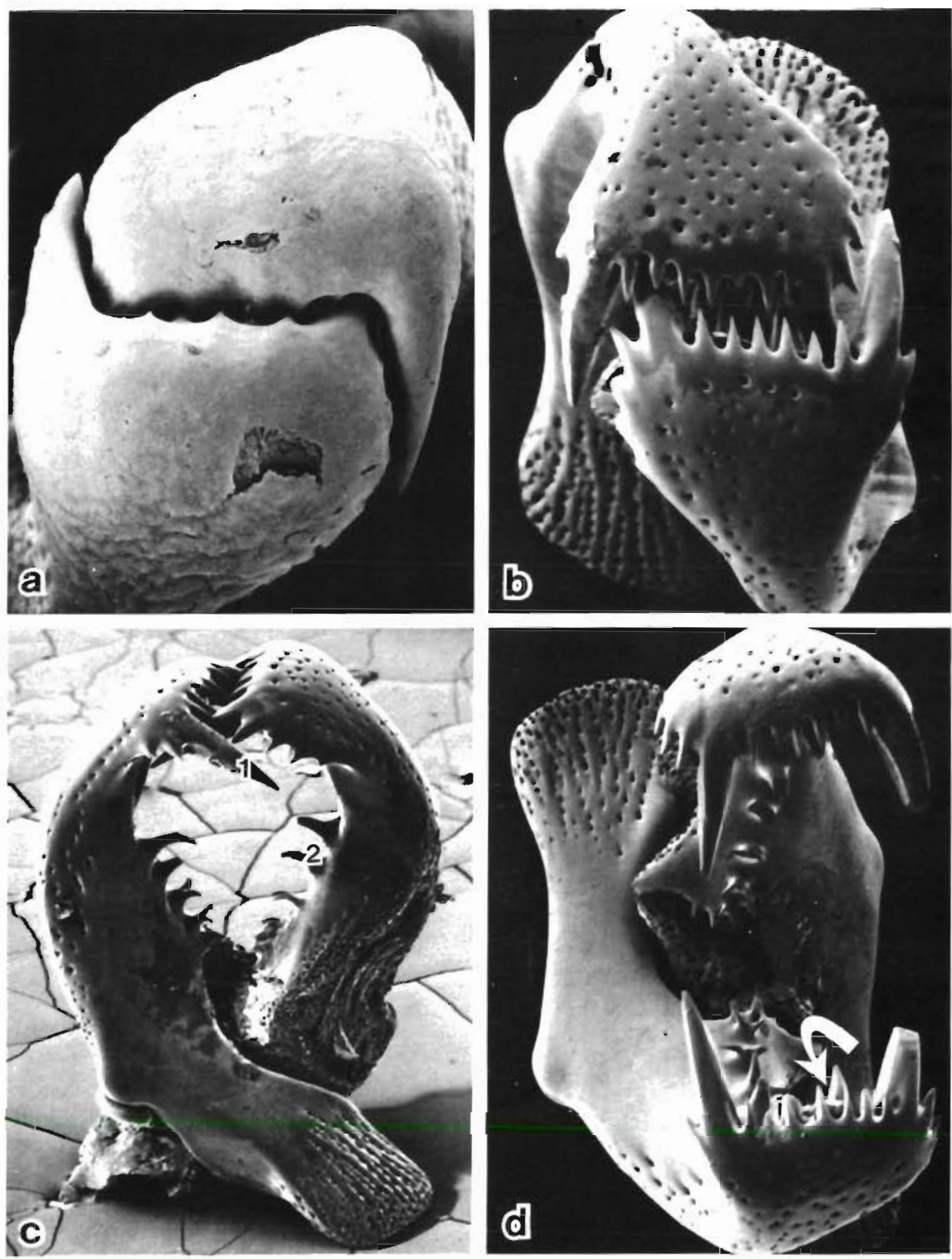

Fig. 6. Labidiaster annulatus. Crossed pedicellariae. (a) Specimen with epidermis intact. Note how closely the teeth of the jaws interlock, $\times 170$. (b) Specimen treated with alkali; interlocking jaws in same relative position as in (a), $\times 90$. (c) Side view of treated jaw pair; 1, 'canine' tooth; 2, median teeth, $\times$ 54. (d) Partially opened pair of treated jaws with the inner distal teeth (arrow) visible together with a portion of the basal (pivot) ossicle (center) $\times 100$

dency for food preferences but acceptance of a wide variety of alternative food sources is a common trait of active predaceous asteroids, e.g. Astropecten americanus (Franz \& Worley 1982), Leptasterias hexactis (Menge 1972), and Pisaster ochraceus (Feder 1959). Dietary data, our laboratory observations, and the tendency for $L$. annulatus to climb all suggest that whenever available, krill are the preferred food. As with krill, amphipods are apparently easily captured by the pedicellariae of this sea star and represent an alternative, highly acceptable prey wherever readily available (e.g. off Visokoi and Zavodovski Islands in the South Sandwich group).

Sediment probably is not an important dietary component of this sea star. The role of sediment in the diet of Labidiaster annulatus (and many other species of 

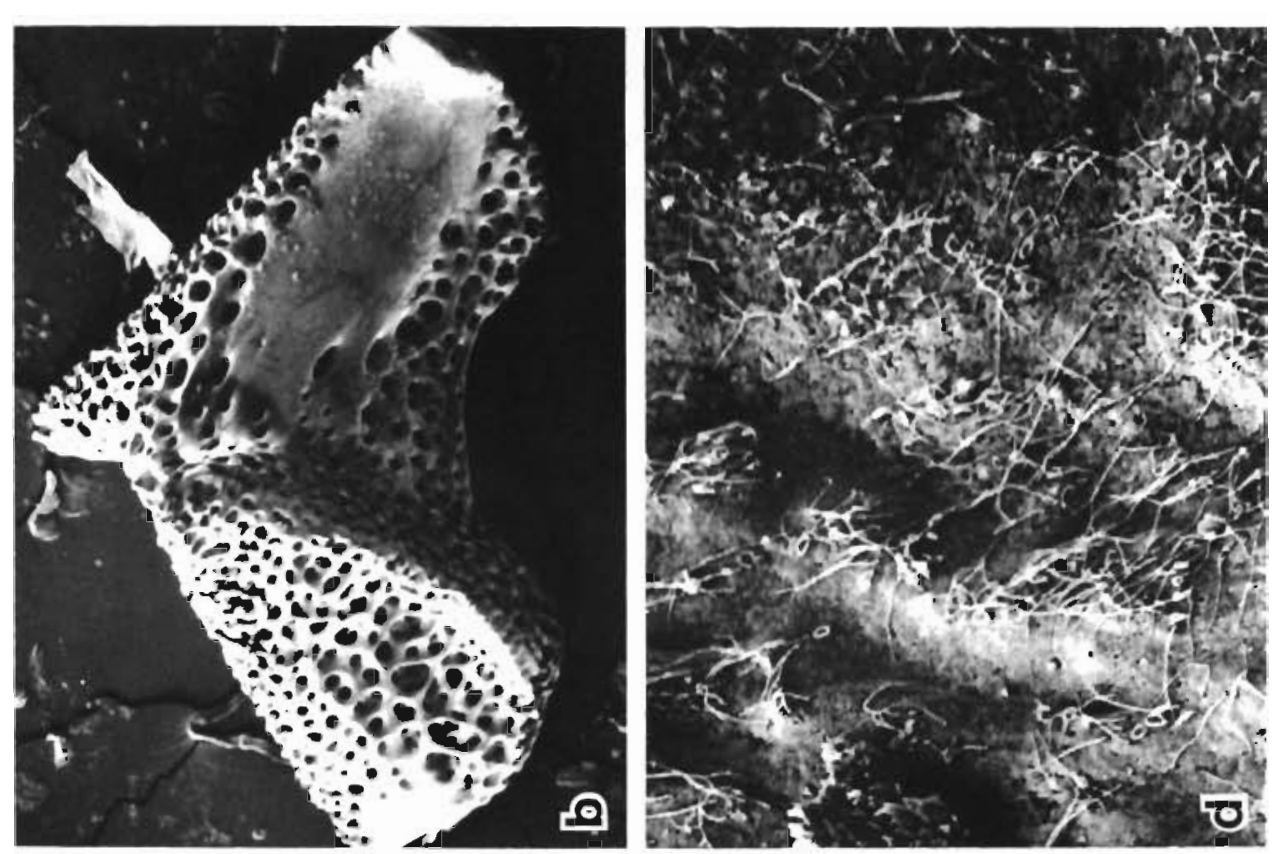

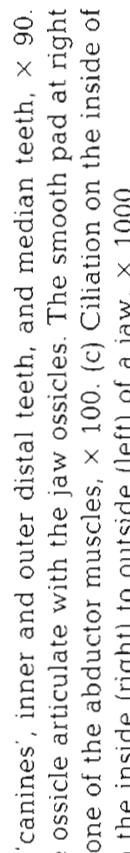
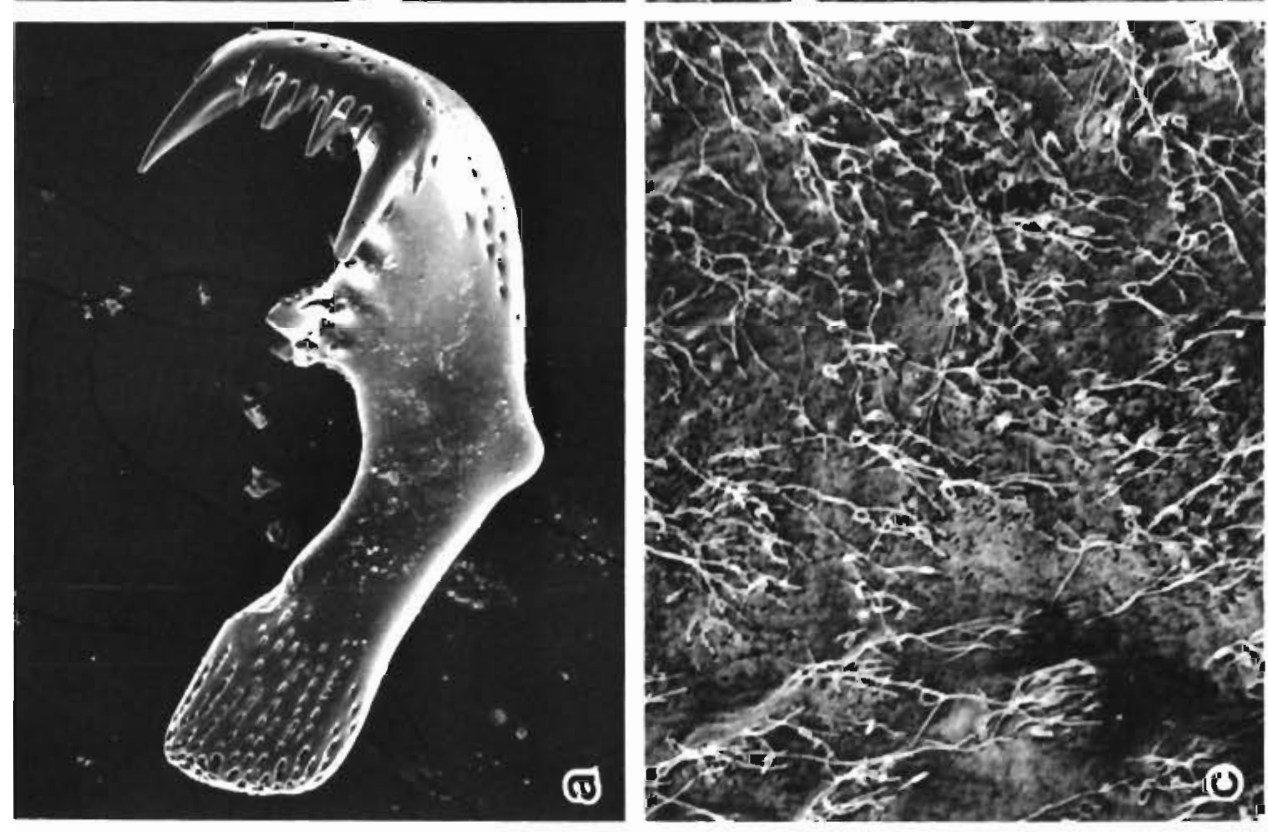

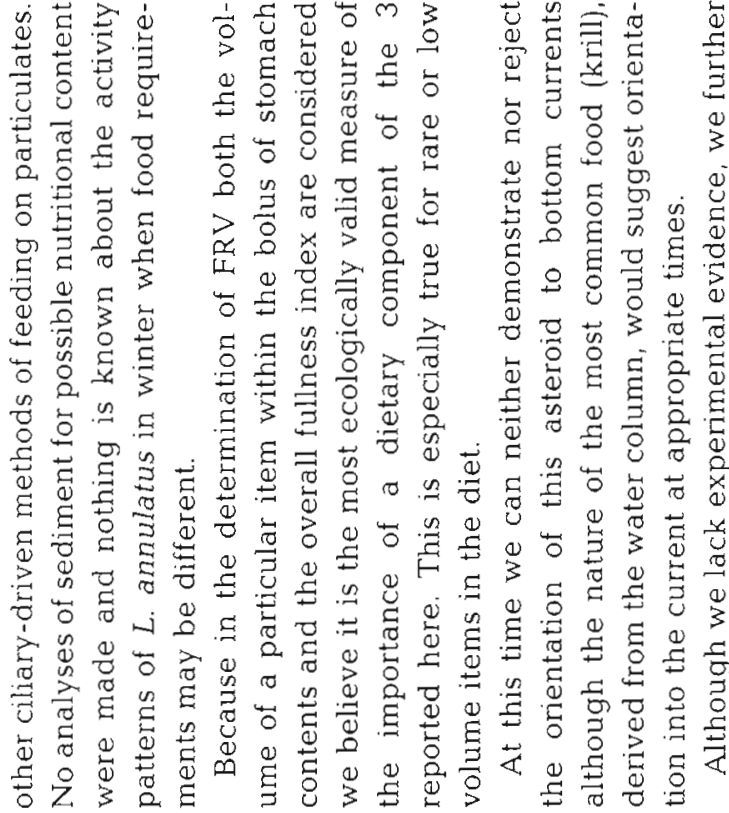

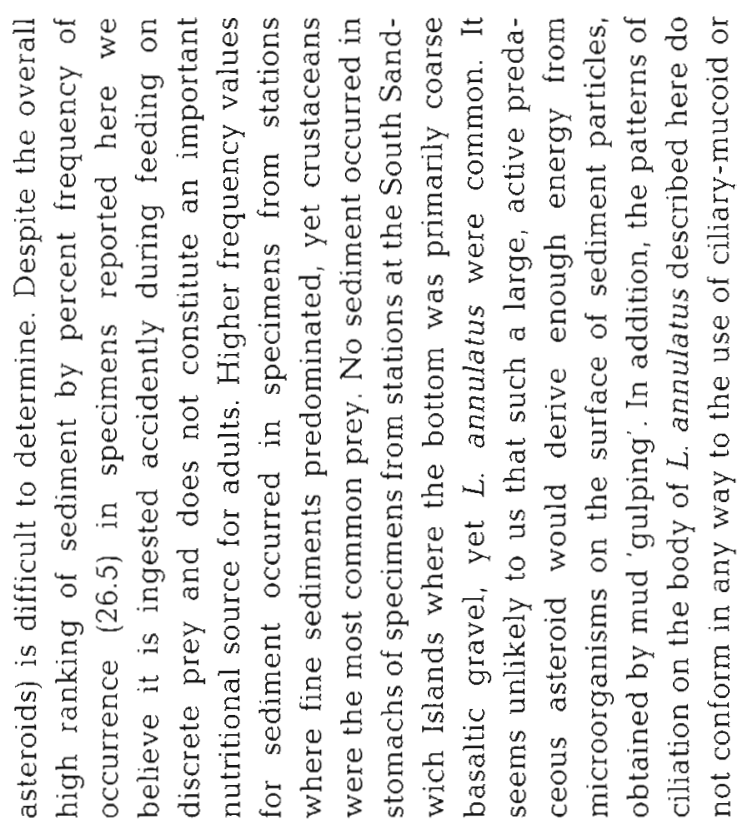



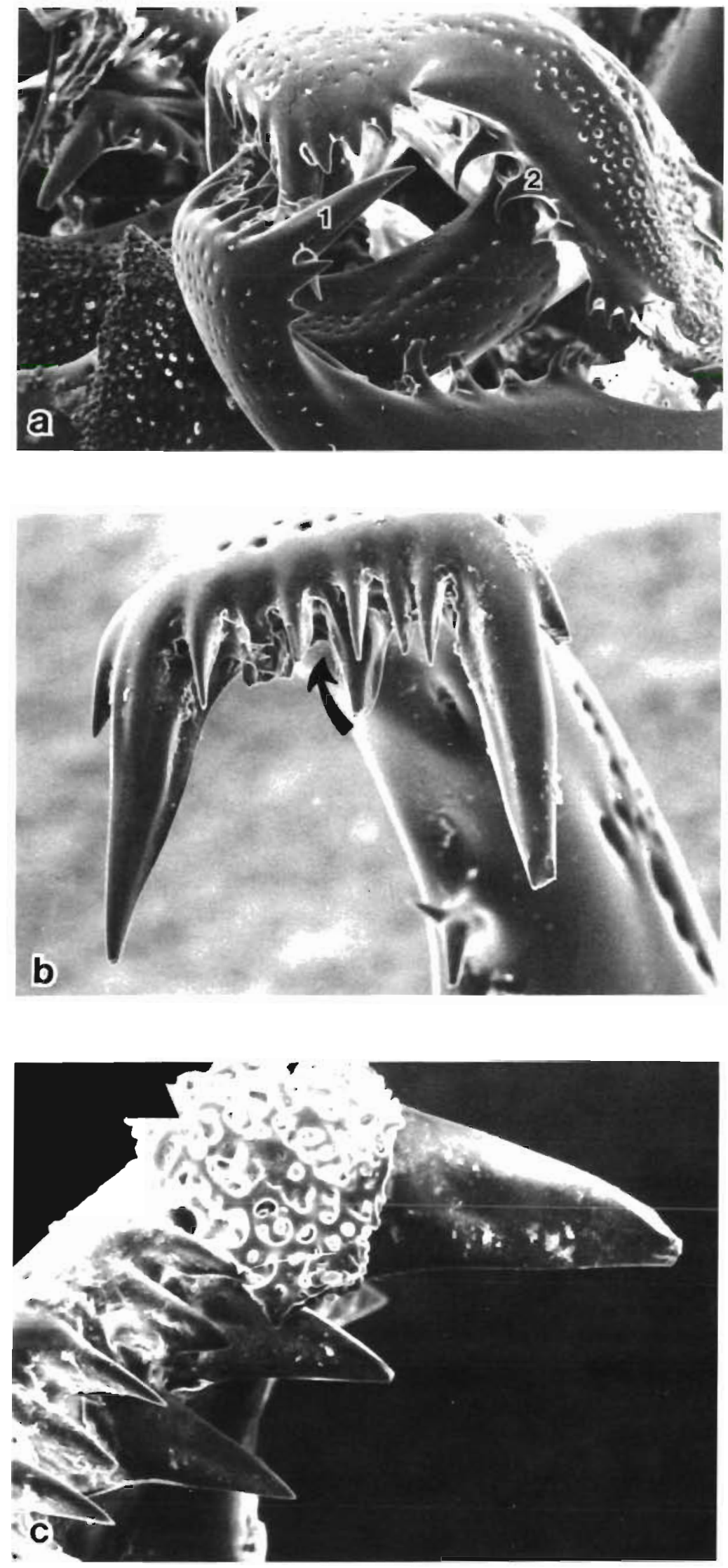

Fig. 8. Labidiaster annulatus. Closeups of distal teeth of the jaws of crossed pedicellariae. (a) Nearly closed pair of jaws; 1 , 'canine' tooth; 2, median tooth, $\times 100$. (b) Dentition of one jaw tip. Note differences in numbers and sizes of outer and inner (arrow) distal teeth, $\times 170$. (c) Echinoderm skeletal ossicle (arrow), probably from an unidentified prey organism, stuck in the teeth, $\times 330$ 

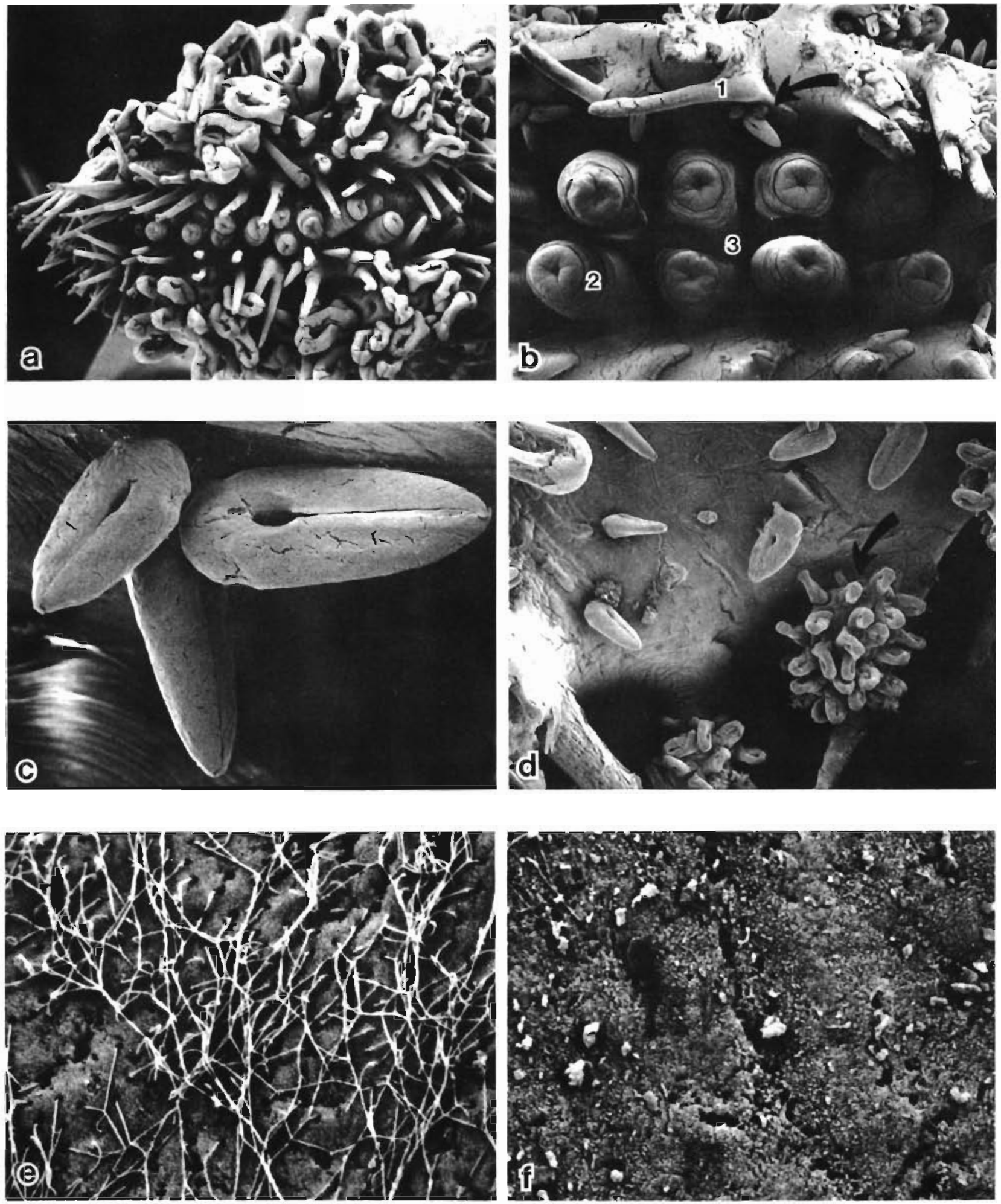

Fig. 9. Labidiaster annulatus. Arm tip and ambulacral region. (a) Oral surface of arm tip showing numerous furrow spines and crossed pedicellariae, $\times 16$. (b) Ambulacral groove near middle of arm; 1, furrow spine with a cluster of small crossed pedicellariae and several larger straight pedicellariae (arrow) at its base; 2 , tube foot; 3 , floor of ambulacrum, $\times 12$. (c) A small cluster of straight pedicellariae along the inside edge of the ambulacral groove, $\times 80$. These clusters are generally associated with the bases of furrow spines as are (d) (arrow), fleshy pads covered with small crossed pedicellariae, $\times 25$; (e) Cilia at the base of a furrow spine, $\times 2300$; (f) Generally unciliated epidermis near the tip of a furrow spine, $\times 2300$ 
suggest that the nutritional state of this sea star is important in its feeding behavior, with the escape of motile prey probably more likely in instances when the sea star is satiated or at least contains some food.

Arnaud et al. (1986) reported that Labidiaster annulatus was relatively rare among large invertebrates at Admiralty Bay, King George Island (South Shetlands), occurring in less than $5 \%$ of samples which included asteroids. At that location $L$. annulatus is an active scavenger at 15 to $90 \mathrm{~m}$ with a tendency for greater abundance in the deeper end of the depth range in summer (Presler 1986). Our data suggest it is more numerous locally at South Georgia, the South Sandwich Islands, and along the Antarctic Peninsula near Anvers Island and the Lemaire Channel region.

The large, crossed, prey-capturing pedicellariae of Labidiaster annulatus are not unique although the ability to grasp and remove from the water column large. active prey such as adult euphausiids and small fishes is uncommon among asteroids. This ability is shared with Stylasterias forreri (Jennings 1907, Robilliard 1971. Chia \& Amerongen 1975) and perhaps other species in this genus. Although the basic anatomy of the pedicellariae is similar in $S$. forreri the specific arrangement of pedicellariae on the aboral surface is quite different, being organized in rosettes on a fleshy ring of skin around the base of each aboral spine (Chia \& Amerongen 1975). Upon sufficient stimulation the rosette elevates up the spine and the pedicellariae open widely and extend away from the spine to present a 'field' of grasping organs toward the prey. In agreement with the interpretation of Chia \& Amerongen for $S$. forreri, the initial contact by the pedicellariae of $L$. annulatus with the prey is made by the sharp caninelike teeth and smaller distal teeth. The curved medial teeth are primarily for retention. With enough pedicellariae firmly clamped on an active, swimming prey, and subsequent use of flexible arms and podia, eventual ingestion becomes probable but not always certain.

In the traditionally aligned Antarctic genus Pedicellaster (Subfamily Pedicellasterinae) individuals are much smaller ( $\mathrm{R}$ rarely exceeds $25 \mathrm{~mm}$ ) than Labidiaster, yet some forms possess relatively enlarged crossed pedicellariae with large terminal or marginal teeth (Clark 1962). However, these are carried primarily on the oral surface in contrast to Labidiaster

Reasons are unclear for the occurrence of the maximum numbers of pedicellariae per annulus on about the 5 th to 8 th annuli before the arm tip. It is uncertain to what degree this is related to the marked decrease in annulus diameter toward the arm tip, a function of arm growth, or whether annuli on the active arm tips are more prone than the remainder of the arm to some loss of crossed pedicellariae, perhaps on escaped prey or due to grazing by fish predators.
Small crossed pedicellariae associated with the ambulacrum apparently do not participate in the initial capture of large prey but perhaps may be involved in capturing small prey and may aid in the transfer of food down the arm toward the peristome.

The lack of tooth development on crossed pedicellariae in small juveniles $(\mathrm{R}<\mathrm{ca} 10 \mathrm{~mm})$ makes it doubtful that such pedicellariae are viable prey-capturing devices at this stage of development. Use of proximal tube feet and the flexible peristome to move and ingest sediment containing small invertebrates is a more likely feeding mechanism in these small juveniles. Switches in dietary patterns accompanying changes in life history stages are known in other asteroids, e.g. herbivore-scavenger to camivore in Acanthaster planci (Moran 1986). The crossed pedicellariae of a larger juvenile $(R=17.3$ ) appear to be fully capable of capturing prey of appropriate size.

In this study our small sample size of juveniles prevented comparison of dietary components or prey size with size of individual Labidiaster annulatus.

Large straight pedicellariae associated with the ambulacrum apparently are defensive and protective and probably serve to keep foreign particles from entering the ambulacrum. We could not determine if they also aid in passing individual prey along the ambulacrum toward the mouth.

We disagree with Dearborn's (1977) conclusion that Labidiaster annulatus and Pycnopodia helianthoides, the largest, heaviest and most active sea star occurring along the western coast of North America (Fisher 1940, Feder 1980, Shivji et al. 1983), are ecological equivalents. These species share several important morphological and ecological features. Both are large and multi-armed, with considerable loss of the aboral skeleton causing the rays to be highly flexible and capable of considerable and rapid torsion. Both occur on varied substrates and may exploit the different prey assemblages occupying these individual habitats. Even the weak, fleshy aboral surface of the disc and arm bases of both asteroids occasionally ruptures from extrusion of undigested parts of certain prey, i.e. gastropod shells for $L$ annulatus (J. H. Dearborn pers. obs.), and gastropod shells and squid pens for P. helianthoides (Wobber 1973).

Structural, dietary and behavioral differences are more important. The crossed pedicellariae of Pycnopodia helianthoides are smaller, commonly 0.35 to $0.45 \mathrm{~mm}$ in length (Fisher 1928), generally less than one half the length of those in Labidiaster annulatus. They are primarily grouped on fleshy stalks in conjunction with spines, unlike the condition in $L$. annulatus. They are apparently not important in prey capture. Although the diets of both species are varied, $L$. annulatus obtains a high percentage of its prey from 
the water column whereas $P$. helianthoides primarily digs out bivalves in soft sediment with its powerful, flexible arms and tube feet and grazes on sea urchins on hard substrates. Lawrence (1987) noted that $P_{y c-}$ nopodia uses its expandable suckered tube feet to excavate the substrate for feeding but not for burrowing. Gastropods, barnacles, crabs, various other infaunal and epifaunal invertebrate prey and carrion (dead squid and fish) can be important locally (Mauzey et al. 1968, Wobber 1973, Paul \& Feder 1975, Shivji et al. 1983 and others; for review see Jangoux 1982). The regular echinoid Sterechinus neumayeri is a common inhabitant in many areas where we found $L$. annulatus, yet this potential prey item occurred in stomachs with a frequency of only $0.7 \%$. For $P$. helianthoides, in contrast, sea urchins (Strongylocentrotus spp.) may account for 21 to $98 \%$ of the diet depending on substrate and availability (Mauzey et al. 1968, Paul \& Feder 1975 , Breen 1979, Shivji et al. 1983). It is the arms and greatly expandable tube feet that are the basic tools of prey capture in $P$. helianthoides. In $L$. annulatus the large crossed pedicellariae and arms work as an integrated system during feeding and the most common prey are active crustaceans, primarily euphausiids, amphipods and mysids, largely obtained from the water column. Here the tube feet apparently function to move prey proximally along the arms following capture.

Acknowledgements. This work has been aided by numerous people whose efforts, often under rigorous circumstances, we gratefully acknowledge. We appreciate the cooperation and logistical support provided by the government of Argentina, especially Captain Julio A. Risso and the officers and crew of ARA 'Islas Orcadas' during our joint Argentine-U.S. cruise to South Georgia and the South Sandwich Islands. We thank Captain Pieter J. Lenie and the crew of RV 'Hero' for outstanding support during cruises along the Antarctic Peninsula, the support staff at Palmer Station, and the following specialists for identification of some prey items: the late Joseph Rosewater (Mollusca) and Judith E. Winston (Bryozoa). Flip Nicklin of the National Geographic Society provided special lighting and other photographic aids for our behavioral studies at Palmer Station. Colleagues Gordon Hendler and Les Watling provided field assistance, good humor, and stimulating discussions. We thank 2 reviewers for their thoughtful comments and John Lawrence for his constructive criticism of the manuscript, advice, and understanding concerning delays in manuscript revision. This study was supported by U.S. National Science Foundation (Division of Polar Programs) grants OPP 74-08565 A01 and DPP 76-23043 to H. H. DeWitt, J. D. McCleave, and J.H.D., and GV-24157 and DPP 79-21537 to J.H.D.

\section{LITERATURE CITED}

Arnaud, P. M. (1964). Echinoderms littoraux de Terre Adélie (Holothuries exceptées) et Pélécypodes commensaux d'Echinides antarctiques. Exp. pol. Françaises, Paris. Publ. 258: $1-72$

Arnaud, P. M. (1970). Frequency and ecological significance of necrophagy among the benthic species of Antarctic coastal waters. In: Holdgate, M. W. (ed.) Antarctic ecology, Vol. 1. Academic Press, London, p. 259-266

Arnaud, P. M. (1974). Contribution a la bionomie marine benthique des régions Antarctiques et Subantarctiques. Tethys 6(3): 465-656

Arnaud, P. M. Jaždžewski, K., Presler, P., Siciński, J. (1986). Preliminary survey of benthic invertebrates collected by Polish Antarctic Expeditions in Admiralty Bay (King George Island, South Shetland Islands, Antarctica). Pol. Polar Res. $7(1-2)$ : 7-24

Bernasconi, I. (1956). Algunos asteroideos de Antartida. An. Soc. cient. Argent. 161: 7-30

Bernasconi, I. (1964). Distribution geografica de los equinoideos y asteroideos de la extremidad austral de Sudamerica. Bol. Inst. Biologia Marina, Mar del Plata 7: 43-49

Bernasconi, I. (1970). Equinodermos Antarticos. II. Asteroideos. 5. Asteroideos de la extremidad norte de la Peninsula Antartica. Museo Argentino de Ciencias Naturales 'Bernardino Rivadavia' Zoologia IX (10): 211-281

Breen, P. A. (1979). Selective feeding of the sunflower star, Pycnopodia helianthoides, in the laboratory. Fish. Mar. Service Manuscript Rept. 1498. Dept. Fisheries and the Environment, Pacific Biol. Station, Nanaimo, British Columbia. $10 \mathrm{p}$.

Brun, E. (1972). Food and feeding habits of Luidia ciliaris Echinodermata: Asteroidea. J. mar. biol. Ass. U.K. 52: 225-236

Carrera-Rodríguez, C. J., Tommasi, L. R. (1977). Asteroidea de la plataforma continental de Rio Grande do Sul (Brasil), coleccionados durante lo viajes del N/Oc, Prof. W. Besnard para el proyecto Rio Grande do Sul. Boletim Inst. oceanogr S. Paulo 26(1): 51-130

Chia, F.-S., Amerongen, H. (1975). On the prey-catching pedicellariae of a starfish, Stylasterias forreri (de Loriol). Can. J. Zool. 53: 748-755

Clark, A. M. (1962). Asteroidea. Rep. B.A.N.Z. antarctic Res. Exped., Ser. B, Vol. IX: 1-104

Dayton, P. K. (1972). Toward an understanding of community resilience and the potential effects of enrichment to the benthos at McMurdo Sound, Antarctica. In: Parker, B. C. (ed.) Proceedings of the colloquium on conservation problems in Antarctica. Allen Press, Lawrence, Kansas, p. $81-95$

Dayton, P. K. (1990). Polar benthos. In: Smith, W O. Jr (ed.) Polar oceanography, Part B, Chemistry, biology, and geology. Academic Press, San Diego, p. 631-685

Dayton, P. K., Robilliard, G. A., Paine, R. T., Dayton, L. B. (1974). Biological accommodation in the benthic community at McMurdo Sound, Antarctica. Ecol. Monogr 44(1): $105-128$

Dearborn, J. H. (1977). Foods and feeding characteristics of Antarctic asteroids and ophiuroids. In: Llano, G. (ed.) Adaptations within Antarctic ecosystems. Proc. Third SCAR Symp. Antarctic Biology. Smithsonian Institution. Gulf Publishing Co., Houston, p. 293-326

Dearborn, J. H., DeWitt, H. H., McCleave, J. D., Targett, T E., Lowe, E. F. (1978). Benthic fishes and echinoderms in the Scotia Arc region. Antarct. J. U.S. 13(4): 137-139

Dearborn, J. H., Edwards, K. C., Fratt, D. B. (1982). Feeding biology of sea stars and brittle stars along the Antarctic Peninsula. Antarct. J. U.S. 16(5): 136-137 (1981 Review)

Dearborn, J. H., Edwards, K. C., Fratt, D. B., Zamer, W. E. (1984). Echinoderm studies along the Antarctic Peninsula. Antarct. J. U.S. 18(5): 193-194 (1983 Review)

Dearborn, J. H., Ferrari, F. D., Edwards, K. C. (1986). Can pelagic aggregations cause benthic satiation? Feeding 
biology of the antarctic brittle star Astrotoma agassizii (Echinodermata: Ophiuroidea). In: Kornicker, L. (ed.) Biology of the Antarctic Seas XVII. Antarctic Res. Ser 44, American Geophysical Union, Washington, D.C., p. 1-28

Dearborn, J. H., Watling, L. E., Edwards, K. C., Fratt, D. B., Hendler, G. (1983). Echinoderm biology and general benthic collecting along the Antarctic Peninsula. Antarct. J. U.S. 17(5): 162-164 (1982 Review)

Dell, R. K. (1972). Antarctic benthos. In: Russell, F., Yonge, C. M. (ed.) Advances in marine biology, 10. Academic Press, London, p. 1-216

DeWitt, H. H. (1976). ARA Islas Orcadas cruise 5. Antarct. J. U.S. 11(2): $48-49$

DeWitt, H. H., McCleave, J. D., Dearborn, J. H. (1976). Ecological studies of fishes and echinoderms during ARA Islas Orcadas cruise 5. Antarct. J. U.S. 11(2): 49-53

Feder, H. M. (1959). The food of the starfish, Pisaster ochraceus, along the California coast. Ecology 40(4): 721-724

Feder, H. M. (1980). Asteroidea: the sea stars. In: Morris, R. H., Abbott, D. P., Haderlie, E. C. (eds.) Intertidal invertebrates of California. Stanford University Press, California, p. $117-135$

Fell, H. B., Dorsey, S. (1969). Asteroidea. In: Bushnell, V. C., Hedgpeth, J. W (eds.) Distribution of selected groups of marine invertebrates in waters south of $35^{\circ} \mathrm{S}$ latitude. Antarctic Map Folio Series, Folio 11, American Geographical Society, New York, p. 41, pls. 24 and 25

Ferrari, F. D., Dearborn, J. H. (1989). A second examination of predation on pelagic copepods by the brittle star Astrotoma agassizii. J. Plankton Res. 11(6): 1315-1320

Fisher, W K. (1928). Asteroidea of the North Pacific and adjacent waters. Part 2. Forcipulata (Part). Smithsonian Inst., Bull. U.S. natn. Mus. 76

Fisher, W. K. (1940). Asteroidea. 'Discovery' Rep. 20: 69-306

Franz, D. R., Worley, E. K. (1982). Seasonal variability of prey in the stomachs of Astropecten americanus (Echinodermata: Asteroidea) from off southern New England, U.S.A. Estuar coast. Shelf Sci. 14: 355-368

Fratt, D. B., Dearborn, J. H. (1984). Feeding biology of the Antarctic brittle star Ophionotus victoriae (Echinodermata: Ophiuroidea). Polar Biol. 3: 127-139

Jangoux, M. (1982). Food and feeding mechanisms: Asteroidea. In: Jangoux, M., Lawrence, J. M. (eds.) Echinoderm nutrition. A. A. Balkema, Rotterdam, p. $117-159$

Jangoux, M. Lawrence, J. M. (ed.) (1982). Echinoderm nutrition. A. A. Balkema, Rotterdam

Jennings, H. S. (1907). Behavior of the starfish, Asterias forreri (deLoriol). Univ. Calif. Berkeley Publ. Zool. 4: 53-185

Lawrence, J. M. (1987). A functional biology of echinoderms. Johns Hopkins Univ. Press, Baltimore

Lawrence, J. M. (1988). Functional consequences of the mul-

This article was presented by J. M. Lawrence, Tampa, Florida, USA tiarmed condition in asteroids. In: Burke, R. D., Mladenov, P. V., Lambert, P., Parsley, R. L. (eds.) Echinoderm biology. Proc. Sixth Inter Echinoderm Conf, A. A. Balkema, Rotterdam, p. 597-602

Mauzey, K. P., Birkeland, C., Dayton, P. K. (1968). Feeding behavior of asteroids and escape responses of their prey in the Puget Sound region. Ecology 49(4): 603-619

McDowell, E. M. (1978). Fixation and processing. In: Trump, B. F., Jones, R. T. (eds.) Diagnostic electron microscopy, Vol. 1. John Wiley, New York, p. 113-139

McKnight, D. G. (1976). Asteroids from the Ross Sea and the Balleny Islands. N.Z. Oceanogr. Inst. Rec. 3(4): 21-31

Menge, B. A. (1972). Foraging strategy of a starfish in relation to actual prey availability and environmental predictability. Ecol. Monogr, 42: 25-50

Menge, B. A. (1982). Effects of feeding on the environment: Asteroidea. In: Jangoux, M., Lawrence, J. M. (eds.) Echinoderm nutrition. A. A. Balkema, Rotterdam, p. 521-551

Moran, P. J. (1986). The Acanthaster phenomenon. Oceanogr. mar. Biol. A. Rev. 24: 379-480

Paul, A. J., Feder, H. M. (1975). The food of the sea star Pycnopodia helianthoides (Brandt) in Prince William Sound, Alaska. Ophelia 14: 15-22

Pearse, J. S. (1965). Reproductive periodicities in several contrasting populations of Odontaster validus Koehler, a common antarctic asteroid. In: Llano, G. A. (ed.) Biology of the Antarctic Seas II. Antarctic Res. Ser. 5, American Geophysical Union, Washington, D.C., p. 39-85

Pearse, J. S. (1969). Antarctic sea star. Aust. Nat. Hist. 16: $234-238$

Picken, G. B. (1985). Marine habitats - benthos. In: Bonner, W N., Walton, D. W. H. (eds.) Key environments - Antarctica. Pergamon Press, Oxford, p. 154-172

Presler, P. (1986). Necrophagous invertebrates of the Admiralty Bay of King George Island (South Shetland Islands, Antarctica). Polish Polar Res. 7(1-2): 25-61

Robilliard, G. A. (1971). Feeding behavior and prey capture in an asteroid, Stylasterias forreri. Syesis 4: 191-195

Shivji, M., Parker, D., Hartwick, B., Smith, M. J., Sloan, N. A. (1983). Feeding and distribution study of the sunflower sea star Pycnopodia helianthoides (Brandt, 1835). Pacif. Sci. $37(2): 133-140$

Sloan, N. A. (1980). Aspects of the feeding biology of asteroids. Oceanogr. mar. Biol. A. Rev. 18: 57-124.

Sloan, N. A., Campbell, A. C. (1982). Perception of food. In: Jangoux, M., Lawrence, J. M. (eds.) Echinoderm nutrition. A. A. Balkema, Rotterdam, p. 3-23

White, M. G. (1984). Marine benthos. In: Laws, R. M. (ed.) Antarctic ecology, Vol. 2. Academic Press, London, p. 421-461

Wobber, D. R. (1973). Aboral extrusion of squid pens by the sea star Pycnopodia helianthoides. Veliger 16(2): 203-205

Manuscript first received: April 17, 1989

Revised version accepted: August 19, 1991 